NBER WORKING PAPER SERIES

\title{
DOES IMMIGRATION AFFECT THE LONG-TERM EDUCATIONAL OUTCOMES OF NATIVES? QUASI-EXPERIMENTAL EVIDENCE
}

\author{
Eric D. Gould \\ Victor Lavy \\ M. Daniele Paserman \\ Working Paper 10844 \\ http://www.nber.org/papers/w10844
NATIONAL BUREAU OF ECONOMIC RESEARCH 1050 Massachusetts Avenue
Cambridge, MA 02138
October 2004

\begin{abstract}
We thank Joshua Angrist and seminar participants at the Hebrew University, the conference on "Inequality, Minorities and Social Exclusion" at Bar-Ilan University, and the CEPR conference on "Inequality in Labour Markets." Vadim Krimsky provided expert research assistance. All errors are our own. The views expressed herein are those of the author(s) and not necessarily those of the National Bureau of Economic Research.

(C)2004 by Eric D. Gould, Victor Lavy, and M. Daniele Paserman. All rights reserved. Short sections of text, not to exceed two paragraphs, may be quoted without explicit permission provided that full credit, including (C) notice, is given to the source.
\end{abstract}


Does Immigration Affect the Long-Term Educational Outcomes of Natives? Quasi-Experimental Evidence

Eric D. Gould, Victor Lavy, and M. Daniele Paserman

NBER Working Paper No. 10844

October 2004

JEL No. I20, J24

\begin{abstract}
This paper uses the mass migration wave to Israel in the 1990s to examine the impact of immigrant concentration in elementary school on the long-term academic outcomes of native students in high school. To identify the causal effect of immigrant children on their peers, we exploit random variation in the number of immigrants across grades within the same school. The results suggest that the overall presence of immigrants had essentially no effect on the quality of the high school attended by native Israelis and on dropout rates, and at most a mild negative effect on high school matriculation rates. However, when we break up the sample by parents' education and by ethnic origin, we find that disadvantaged children were more likely to have been adversely affected by a higher immigrant concentration in elementary school. Focusing on the impact of Ethiopian immigrants who are from a much lower socio-economic background, we find stronger evidence of adverse effects, especially for disadvantaged students and in classes where immigrant concentration was particularly high.
\end{abstract}

Eric D. Gould

Department of Economics

Hebrew University

Mount Scopus

91905 Israel

mseric@mscc.huji.ac.il
Victor Lavy

Department of Economics

Hebrew University

Mount Scopus

91905 Israel

and NBER

msvictor@mscc.huji.ac.il

\author{
M. Daniele Paserman \\ Department of Economics \\ Hebrew University \\ Mount Scopus \\ 91905 Israel \\ dpaserman@nn-shum.cc.huji.ac.il
}




\section{Introduction}

An increasingly important issue faced by Western countries at the turn of the $21^{\text {st }}$ century is the social tension created by growing numbers of immigrants from less developed countries. Questions about the effects of immigration on the labor market, on the wage distribution, on the welfare system, and on crime and personal security, are hotly debated in both the United States and Europe. Social tensions may manifest themselves particularly acutely inside the school system. A disproportionate share of school resources is likely to be devoted to immigrants, for at least two important reasons. First, the gap in fertility rates between immigrants and the native-born implies that a large and growing share of the school population is made up by immigrants or immigrants' children. For example, in 2003, more than 50 percent of first-grade children in California's public schools were classified as Hispanic/Latino, as opposed to only 42 percent among eighth-graders. ${ }^{1}$ Second, immigrant children have to cope with the difficulties associated with the adoption of a new language, and therefore may necessitate more one-to-one teaching, remedial classes, adjunct teachers, and so forth. It is then natural to ask whether the presence of immigrants in a school has adverse effects on the academic achievements and human capital accumulation of native students.

This question is linked to the broader issue of how the environment and peers affect individual outcomes. Despite the important theoretical advances in the analysis of social interactions, question marks still abound, mainly because of the inherent difficulty in providing convincing empirical evidence on their existence and magnitude. The main problem is that if members of the same group are observed to behave similarly, it is generally impossible to infer whether this is due to true peer effects, or to individuals sorting themselves endogenously into groups that share common characteristics. In the classroom context, since essentially all the variation in the quality of one's peers is due to the endogenous choices of parents and school administrators, the identification problem is particularly acute.

\footnotetext{
${ }^{1}$ Source: California Department of Education.
} 
In this paper, we exploit a unique opportunity to identify peer effects in the classroom using the mass migration wave from the former Soviet Union ("FSU") to Israel in the early 1990's. In particular, we examine the impact of immigrant concentration in fifth grade on the long-term academic outcomes of native students in high school. The focus on the long-term outcomes of natives, around seven years after their exposure to the "treatment," is one of the distinguishing features of this paper.

The population under investigation is that of Jewish children who were enrolled in $5^{\text {th }}$ grade during the 1993-1994 school year. The extent of the exposure of native children to immigrant peers is determined primarily by the residential distribution of immigrants across the country. Upon landing in Israel, immigrants were directed either to temporary housing made available by a selected number of municipalities, or to dedicated absorption centers located throughout the country. The initial absorption locality was chosen by FSU immigrants before their arrival in Israel, and they tended to locate in poorer areas where housing costs were low. As a result, although immigrants can be found over the whole spectrum of Israeli public schools, schools with larger immigrant concentrations also tended to have native students with lower average achievements. This non-random sorting of immigrants into locations invalidates an estimation strategy based on a simple regression of native outcomes on the fraction of immigrants in the same school.

Instead, we exploit random variation in the number of immigrants across grades within the same school. More specifically, we argue that conditional on the total number of immigrants in a given school in grades 4 to 6 , the actual number of immigrants in grade 5 is determined by random factors such as variation in the year of birth among the pool of immigrant children in the school district. This natural experiment is best thought of as the random drawing of balls from an urn in which one third of the balls are marked with the number " 4 ", one third with the number " 5 ", and one third with the number "6". Conditional on the total number of balls drawn, the number of " 5 " balls is as good as randomly assigned. 
Conditioning on the total number of immigrants in the advanced grades in elementary school removes much of the heterogeneity across schools that may confound our estimates: schools that absorbed the same number of immigrants are likely to be similar among themselves, not only in their propensity to absorb immigrants, but also in other characteristics.

Indeed, a set of balancing tests indicate that, conditional on the number of immigrants in grades 4 to 6 and the total number of children (natives and immigrants) in grade 5 , there is essentially no correlation between observable background covariates (such as parental education) and the percentage immigrants in $5^{\text {th }}$ grade. This finding justifies our identifying assumption that there is no correlation between unobservable characteristics of native children and the percentage immigrants in $5^{\text {th }}$ grade, after conditioning on the same set of controls.

We use administrative panel data on school enrollment and test scores to follow each $5^{\text {th }}$ grade child from the 1993-1994 school year until the 2000-2001 school year, the year this cohort was scheduled to graduate from high school. After regressing the high school achievements of native students on the percentage of immigrants in their $5^{\text {th }}$ grade, we find that the concentration of immigrants in elementary school has essentially no effect on the quality of the high school attended by native children and on their dropout rates, while it has at most a mild effect on high school matriculation rates. However, after performing the analysis separately on different samples of natives according to their parents' years of schooling and ethnic origin, a consistent pattern emerges whereby disadvantaged children appear more likely to have been adversely affected by a higher concentration of immigrants among their peers. We also replicate our analysis looking only at the concentration of Ethiopian immigrants who arrived in May 1991 in "Operation Solomon." We do find stronger evidence of adverse effects in this specification, and especially so for disadvantaged students and in schools where the immigrant concentration was particularly high.

In spite of some unique characteristics of the mass migration wave to Israel, we believe that the paper is relevant beyond the local context for several reasons. First, the number of 
immigrants to Western Europe and the United States from the former communist countries of Central and Eastern Europe has also risen steeply in the past decade. This number is expected to grow following the enlargement of the European Union. As a result, it is likely that a large fraction of future immigrants to Western European countries will share many of the characteristics of immigrants to Israel. Second, as more Western countries debate whether to move toward a more skill-biased immigration policy, it may be important to learn and implement the lessons from the highly skilled migration wave to Israel. We should also keep in mind that the number of highly skilled immigrants in the West is already non-negligible. In the United States in the year 2000, the fraction of recent immigrants with a college degree is slightly larger than that of natives (22.0 percent versus 20.9 percent), and in some states it is substantially larger. ${ }^{2}$

While there is a vast literature on the effects of immigration on native labor market outcomes, ${ }^{3}$ the question of whether immigration affects natives' educational outcomes has received relatively little attention. Exceptions include Betts (1998), who examines whether immigration reduces the contemporaneous high school graduation rate of natives, and Hoxby (1998) and Borjas (2004), who look at whether immigrants crowd-out natives from slots in college and graduate programs. In a similar vein, Betts and Fairlie (2003) investigate whether immigration in California induced native flight from public to private schools. Closely related to our paper is also the literature on desegregation and classroom peer effects: Angrist and Lang (2002) study the effects of Metco, a long-running desegregation program that sends minority children out of the Boston public school district to a large and affluent suburban district. Overall they find little evidence that the test scores of non-Metco students are affected by the presence of disadvantaged peers, although there seems to be some evidence of a

\footnotetext{
${ }^{2}$ In Ohio, the fraction of immigrants with a college degree is 37.4 percent, versus 17.6 percent among natives; in Michigan, it is 33.2 percent among immigrants versus 17.2 among natives; in Pennsylvania, it is 33.1 percent among immigrants versus 19.0 among natives. Source: 2000 Census of Population.
} 
negative effect on the test scores of non-Metco minority students. Guryan (2001) studies the effects of desegregation from the 1950s to the 1980s, and concludes that black dropout rates fell as a result of desegregation, while desegregation did not affect the dropout rates of whites. Hoxby (2000a) uses an identification strategy similar to our own, exploiting idiosyncratic variation in gender and race composition of adjacent cohorts in Texas public schools, and in a wide range of specifications she finds that children's elementary school test scores are affected by those of their peers, with intra-race peer effects appearing to be particularly strong. ${ }^{4}$ In contrast to Hoxby, our focus is on the effect of immigrants on natives and we examine long-run effects, rather than the contemporaneous effects of peers.

Sacerdote (2001) and Zimmermann (2003) study peer effects in a university setting, and find that academic and social outcomes of college students are affected by the quality of randomly assigned roommates. Recent years have also seen a flurry of research that uses exogenous variation created by true or natural experiments to study the effects of peers and the environment at the neighborhood level on a variety of educational, health, and economic outcomes (Katz, Kling and Liebman, 2001; Edin, Fredriksson and Åslund, 2003; Oreopoulos, 2003; Jacob, 2003; Weinberg, Reagan and Yankow, 2004). In our previous study (Gould, Lavy and Paserman, 2004), we found that Ethiopians who arrived during Operation Solomon generally benefited from attending better schools. However, before claiming that sending immigrants to better-performing schools represents a net gain from the point of view of society, it is crucial to assess whether children in immigrant or minority-receiving schools are affected by the influx of disadvantaged peers, as we set out to do in the current study.

The rest of the paper is structured as follows: the next section presents a brief background of the immigration to Israel in the 1990s and describes our data. Section 3

\footnotetext{
${ }^{3}$ See for example Card (1990, 2001); Altonji and Card (1991), Lalonde and Topel (1991), Hunt (1992), Borjas, Freeman and Katz (1996), Borjas (2003); in the Israeli context, see Friedberg (2001) and Cohen-Goldner and Paserman (2004a, 2004b).

${ }^{4}$ An identification strategy based on random variation in cohort size at the school level is also used by Angrist and Lavy (1999) and Hoxby (2000b) to estimate the effects of class size on student achievements.
} 
describes the empirical methodology and the identification strategy. Section 4 presents the basic results on the effect of immigration on natives' long-term scholastic achievements. Section 5 repeats the analysis using the percentage of Ethiopian immigrants from Operation Solomon as the explanatory variable. Section 6 concludes.

\section{Background and Data}

The mass migration from the former Soviet Union to Israel since 1989 can be viewed as a unique laboratory for the social sciences. More than one million immigrants moved to Israel since 1989, increasing its population by a remarkable 20 percent within a decade. The migration wave was also highly concentrated, with approximately 330,000 immigrants arriving in 1990 and 1991. The fall of the Berlin wall in November 1989 was the trigger that started the whole process, as a number of factors combined to induce migration. First, the Soviet Union lifted its emigration restrictions. Second, the political instability and the uncertain economic climate in the beginning of the 1990s greatly increased the incentives to migrate. Third, Israel was one of the few viable options, as it imposed no entry restrictions and no lengthy waiting periods. Along with the mass migration from the former Soviet Union, the early 1990 s also saw the exodus of 15,000 Ethiopian Jews in the context of Operation Solomon in May 1991, and increasing immigration rates from other countries, mainly the United States and Argentina.

Not surprisingly, there are large differences in the family background of immigrants from Ethiopia versus the former Soviet Union, and the overall immigrant population is quite different in family background from native Israelis. These differences are displayed in Table 1, which shows the background characteristics of $5^{\text {th }}$ grade students in 1994 according to data collected by the Ministry of Education, and the characteristics of households with children between the ages of 8 and 12 from the 1995 Census. Table 1 reveals that immigrant children from the former Soviet Union generally have parents who are more educated than native 
Israeli children (a little more than one additional year of education for each parent), but come from smaller families (1.10 siblings versus 2.41 for native Israelis). In contrast, Ethiopian immigrant children come from much larger families (an average of 4.28 siblings) but have parents with only one or two years of education. However, the vast majority of immigrants during this period came from the former Soviet Union, so the characteristics of the overall immigrant population are dominated by the characteristics of the Russian immigrants.

While it appears that native Israeli children were exposed to a new immigrant population with more favorable family background characteristics, it is also true that the new immigrant population displayed several signs of social and economic distress. Compared to native Israeli children, Table 1 reveals that immigrant children came from poorer households which tend to rent rather than own their own homes, and where the head of the household is much more likely to be unemployed or female. Once again, the Ethiopian immigrants display much larger signs of weakness compared to the Russians, but both groups of immigrants are less favorable compared to the native Israeli population. So, while it is true that the overall immigration wave of this period flooded the country with immigrants who were generally more educated than the average Israeli, the overall picture reveals that these immigrants displayed several signs of socio-economic difficulties, which made them weaker in many ways than the native population.

To examine whether the influx of this immigration wave into elementary schools influenced the high school outcomes of native Israeli children several years later, we link detailed information on each child's school environment in the 5th grade to the achievements of each student throughout high school. The data comes from administrative records collected by Israel's Ministry of Education on the universe of Israeli elementary schools in the 19931994 school year, the first year a computerized file is available. The data is based on reports from school authorities to the Ministry of Education at the beginning of the school year. The file contains an individual identifier, a school and class identifier, and detailed demographic 
information on all immigrant pupils in grades 1 to 6 , and all pupils in grades 1,2 , and 5 . We are able to exactly identify pupils by their country of origin and date of immigration (month and year), so we know precisely who is a native Israeli student and how many immigrant children were present in the $5^{\text {th }}$ grade class of each elementary school. We focus our attention on the 5th grade cohort in 1993-1994 for two reasons. First, the data for native Israeli pupils is incomplete for $4^{\text {th }}$ and $6^{\text {th }}$ grades. Second, $5^{\text {th }}$ grade students in the 1993-1994 school year had enough time within our sample period (which ends with the 2000-2001 school year) to finish high school if they progressed through the system without repetition.

We link the elementary school records to individual data on high school enrollment and matriculation exam outcomes in the 1998-1999, 1999-2000, and 2000-2001 school years. Therefore, we are able to follow each native Israeli student from $5^{\text {th }}$ grade in 1993 all the way through the advanced stages of high school. We study three different high school outcomes: the quality of the high school attended (measured by the average passing rate of high school students in the same school on the matriculation exams from 1996-1998), dropping out before completing $12^{\text {th }}$ grade, and passing the matriculation exams. The latter outcome is particularly important in Israel since it is required to attend college. Similar high school matriculation exams are found in many countries and in some states in the United States. Examples include the French Baccalaureate, the German Certificate of Maturity (Reifezeugnis), the Italian Diploma di Maturità, the New York State Regents examinations, and the recently instituted Massachusetts Comprehensive Assessment System.

Table 2 presents summary statistics for various measures of the $5^{\text {th }}$ grade learning environment faced by native Israeli students. We classify the learning environment variables into two groups, "peer characteristics" and "school characteristics". The "peer characteristics" describe the family background of the native Israeli $5^{\text {th }}$ grade students in the school. The "school characteristics" contain additional aspects measured at the school level (average scores for the $4^{\text {th }}$ and $5^{\text {th }}$ grade students on the 1991 standardized math and verbal 
tests $^{5}$ and a 1991 socio-economic index of students in each elementary school ${ }^{6}$ ), and several characteristics of the population in the school's district (income per capita, unemployment rate, welfare recipiency rate, and local high school passing rate on matriculation exams). ${ }^{7}$ All of the "school characteristics" are taken from data from the 1991 school year, which is two years before the sample of native students used in Table 2 attended $5^{\text {th }}$ grade.

Summary statistics are presented in four columns in Table 2, whereby the sample used in each column is defined by the total number of immigrants absorbed into the elementary school in grades 4 to 6 . For example, the first column presents summary statistics only for the native Israeli $5^{\text {th }}$ graders who attended an elementary school in 1993-1994 where the total number of post-1989 immigrants in grades 4 to 6 was between 1 and 10 . The next column uses a range of immigrants in $4^{\text {th }}$ to $6^{\text {th }}$ grades between 11 and 20 , and the next two columns use ranges of 21-30 and 31-40 respectively.

A close inspection of the numbers in Table 2 reveals why it is important to break down the sample in this manner. When comparing the means across columns, a clear pattern emerges: schools with larger numbers of total immigrants in grades 4 to 6 are increasingly worse off in terms of the characteristics of the native Israeli students in the same school. For example, as the number of immigrants in the school increases, the parental education of native students falls, the percent of students with origins from Asia and Africa (which is widely considered to be a disadvantaged ethnic group in Israel) increases, the average math and verbal scores of the elementary school fall, and the socio-economic index of the school falls.

\footnotetext{
${ }^{5}$ In June of 1991, near the end of the school year, all fourth and fifth grade students were given achievement tests designed to measure mathematics and Hebrew reading skills. The scores used here consist of the average score on some of the basic and all of the more advanced questions in the test, so that scores are scaled from 1 to 100. The low average and the high variation of scores on this achievement test generated considerable public controversy in Israel, leading to the abandonment of the national testing program in 1992. This is the same data used in Angrist and Lavy [1999].

6 The socioeconomic index is based on a function of the pupils' fathers' education and continent of birth, and of family size. The raw index is recorded as the percentage of students in the school who come from what is defined to be a disadvantaged background. Our socioeconomic status index is obtained by standardizing this variable and multiplying it by -1 , so that high socioeconomic status schools have a high value of the index.

7 This data was originally collected from a variety of administrative sources by Shitrit and Dor [1994] and Applebaum, Dor and Heimburg [1996].
} 
In addition, immigrants represent only 4.04 percent of the $5^{\text {th }}$ grade class when the total number of immigrants in $4^{\text {th }}$ to $6^{\text {th }}$ grades is between 1 and 10 , but increases to 15.47 percent when there are 31-40 immigrants in the same three grades. Overall, a clear pattern emerges where larger numbers of immigrants in grades 4 to 6 are associated with larger concentrations of immigrants in $5^{\text {th }}$ grade, weaker native Israeli students based on their family background, and weaker schools based on the performance of students in the school in previous years. These results are not very surprising since new immigrants were not placed or directed to areas where the best schools and most-educated parents are likely to be. Instead, immigrants typically started out in areas with lower-cost housing, and therefore native Israelis from disadvantaged backgrounds and lower-performing schools were more likely to attend schools with higher concentrations of immigrants.

The lower panel of Table 2 presents the high school outcomes of native Israeli students according to the number of immigrants in grades 4-6 in their school in 1993-1994 while they were in $5^{\text {th }}$ grade. Not surprisingly, the lower panel of Table 2 indicates that native students who attended schools with a larger concentration of immigrants in $5^{\text {th }}$ grade also had lower outcomes in high school: they attended lower quality high schools, ${ }^{8}$ dropped out of high school more often, and were less likely to pass the matriculation exams.

However, it is impossible to determine that natives who attended elementary schools with more immigrants achieved less in high school because of the increasing presence of immigrants, or whether a larger concentration of immigrants is simply correlated with other observed and unobserved background and school-level characteristics which are responsible for their success or failures. Because the enrollment of immigrants across schools was not random, it is not valid to draw inferences about a causal relationship when we know that a disproportionate number of immigrant students winded up with native Israeli students who

\footnotetext{
${ }^{8}$ While the assignment of children to elementary schools is based on zoning, enrollment in high schools is determined by a selection process reflecting choices by students, parents, and schools. Therefore, the quality of high school attended can be reasonably viewed as an outcome variable.
} 
were weaker in family background and were attending elementary schools with lower performance records. Therefore, our empirical strategy will try to overcome this identification problem by comparing the exposure of immigrants in the fifth grade, while holding the number of total immigrants in the school to within a narrow range.

\section{Identification Strategy}

To estimate a causal effect of the presence of new immigrants on their native Israeli peers, we need variation in the presence of immigrant children in the classroom that is uncorrelated with the background and school characteristics of the native children. It is clear from Table 2 that immigrant students were not distributed into schools in a manner uncorrelated with the background characteristics of the native Israelis. The presence of immigrant students in the $5^{\text {th }}$ grade class is not a random event - native students in poorer and lower achieving schools are more likely to attend schools with larger concentrations of immigrant students. In general, the non-random assignment of children to schools, either because of the choice of schools exercised by the families, or because of the endogenous matching of pupils to schools done by education authorities, makes it difficult to identify the effect of one group of peers on the outcomes of others. As such, the identification of a causal link between peers has proven to be a difficult task in the literature. To overcome this obstacle, our strategy is to exploit random variation in the number of immigrants in $5^{\text {th }}$ grade conditional on the school absorbing a given range of immigrant students in grades 4 to 6 .

\section{Methodology}

Formally, we define the treatment variable $t$ as the percentage of immigrant students in grade 5 in a given school:

$$
t=100 \times \frac{\text { Number of immigrants in grade } 5}{\text { Number of children in grade } 5}
$$


We have a random sample of units, indexed by $i=1,2, \ldots, N$. For each unit, we postulate the existence of a potential outcome, $Y_{i}(t)$, for $t \in[0,100]$. We observe for each unit the actual treatment $T_{i}$ and a set of covariates $X_{i}$. The observed outcome for unit $i$ is $y_{i}^{o b s}=\sum_{t \in T} 1\left(T_{i}=t\right) Y_{i}(t)$

\section{Assumption 1 (Conditional random assignment):}

$Y(t)$ independent of $T \mid X, \quad$ for all $t \in[0,100]$.

\section{Assumption 2 (Constant linear treatment effect):}

$$
Y_{i}(t)=Y_{i}(0)+\beta t
$$

The first assumption is at the heart of our identification strategy: in our case, the critical conditioning covariates are the number of immigrant children in grades 4 to 6 , and the total number of children in grade 5. We know that schools that absorbed large numbers of immigrants are different in terms of student and school characteristics relative to schools that absorbed fewer immigrants. However, holding constant the number of immigrant children in grades 4 to 6 , the number of immigrants in grade 5 (the numerator in the treatment variable) is determined solely by random variation in birth years among the pool of immigrant children in a school district. Since the treatment variable is the immigrant ratio, we must also condition on the total number of children in grade 5. Once again, our argument is based on the assumption that among schools of the same size that absorbed the same number of immigrant children, variation in the percentage of immigrants in grade 5 is determined primarily by random variation in the size of each immigrant cohort.

We now consider the expectation of the observed outcome, conditional on the actual treatment received and on the covariates:

$$
\begin{aligned}
& E\left(y^{o b s} \mid T=t, X=x\right)=E\left[\sum_{t \in T} 1(T=t) Y(t) \mid T=t, X=x\right] \\
& =\sum_{t \in T} 1(T=t) E[Y(t) \mid T=t, X=x] \\
& =E[Y(0)+\beta t \mid T=t, X=x]=E[Y(0) \mid X=x]+\beta t
\end{aligned}
$$


where the last equality follows from the conditional random assignment assumption. The above formulation illustrates that, conditional on any particular value of the covariates, we can obtain a consistent estimate of the treatment effect $\beta$ by running a regression of the observed outcome on a constant and the treatment variable.

In practice, this approach is not feasible, because the two key conditioning covariates are essentially continuous, so that there are not enough observations for any given value of $X$. For example, there are few native students who attended schools with a particular number of total students in grade 5 and a particular number of total immigrants in grades 4 to 6 . Therefore, we divide the sample into eight different intervals defined by the number of immigrants in grades 4 to 6 in a given school: the first interval includes schools with 1 to 5 immigrants in grades 4 to 6 , the second interval includes schools with 6 to 10 immigrants in grades 4 to 6 , and so on. Then, within each interval, we regress the outcome variable on the treatment and on a flexible function of the key conditioning variables. This control function, as it is known in the literature, is meant to capture the term $E[Y(0) \mid X=x]$ in equation (1). In practice, the control function will include the number of immigrants in grades 4 to 6 , the total number of children in grade 5, the squares of these two variables, the interaction between the two, and, in some specifications, additional individual and school characteristics entered linearly. Note that since the exact functional form of $E[Y(0) \mid X=x]$ is unknown, estimating equation (1) on the full sample imposes the specific functional form assumption globally, and may be misleading. Instead, by dividing the sample into narrow intervals on the basis of the number of immigrants in grades 4 to 6 , we are less likely to induce bias in our estimates by our local approximation to $E[Y(0) \mid X=x]$.

Summing up, within each interval we run the following regression to explain the high school outcome of native Israeli student $i$ who attended elementary school $j$ : 


$$
\begin{aligned}
(\text { High School Outcome })_{i j} & =\lambda_{0}+\alpha(\text { Percent Immigrants in } 5 \text { th Grade })_{j} \\
& +\lambda_{1}(\text { Family Background })_{i} \\
& +f(\# \text { of immigrants in grades } 4 \text { to } 6, \# \text { of children in grade } 5)_{j}+u_{i j},
\end{aligned}
$$

where the treatment parameter, $\beta$, is identified by the conditional random assignment assumption described above. Since the percent of immigrants in $5^{\text {th }}$ grade does not vary at the individual level, the standard errors are adjusted for clustering at the elementary school level. The average treatment effect can be calculated by simply taking the weighted average of the coefficients within each interval. Alternatively, one can pool all intervals together, and then regress the outcome variable on the treatment effect, a dummy variable for each one of the intervals, and the interactions of this dummy with each one of the conditioning variables. This specification is equivalent to running separate regressions within each sub-sample, but constraining the coefficient on the treatment variable to be the same across sub-samples. It is potentially more efficient, as data from the whole sample is pooled together to obtain one single estimate of the treatment effect. In the tables that follow, we refer to this model as the "fully interacted" model.

\section{$\underline{\text { Balancing Tests }}$}

To determine whether the data supports our identification strategy, we now test whether there is a significant relationship between the percent of immigrants in grade 5 and the observable characteristics of native Israeli children in the various sub-samples of schools defined by the total number of immigrant children in grades 4 to 6 . This is done by regressing various measures of the native student's background or elementary school environment on the percent of immigrant students in the school's $5^{\text {th }}$ grade for the eight sub-samples. If the assignment of immigrant students across the $4^{\text {th }}, 5^{\text {th }}$ and $6^{\text {th }}$ grades within the same school is indeed random once we condition on the narrow range of total immigrants in the school and on the control function, then we should find no such significant relationship. 
The balancing tests described above do not necessarily provide a proof of random assignment, as the assumption requires there to be no correlation between the percentage immigrants in $5^{\text {th }}$ grade and both observable and unobservable background characteristics. However, the lack of a significant relationship between the presence of percentage immigrants in $5^{\text {th }}$ grade and observable characteristics suggests that it is unlikely that such a relationship exists between percentage immigrants in $5^{\text {th }}$ grade and unobservable characteristics. The results of these tests are presented in Table 3.

Each coefficient in Table 3 represents the estimate from a single regression for each of the various measures of the native student's background and elementary school environment on the percent of immigrants in $5^{\text {th }}$ grade. Out of the 64 coefficients, only five of them are significant at the ten percent significance level or lower. The other 59 coefficients point to no systematic relationship between observable characteristics and the percent of immigrants in $5^{\text {th }}$ grade. Furthermore, the remaining five coefficients which do turn out to be statistically significant do not tell a consistent story about whether students are positively or negatively selected into schools with larger percentages of immigrants in the $5^{\text {th }}$ grade (holding constant the range of immigrant students in grades 4 to 6). For example, the second column reveals that higher proportions of immigrants in $5^{\text {th }}$ grade are significantly associated with larger families and lower class sizes, which leads to contradicting inferences about negative or positive selection. A similar phenomenon is found in column three where a higher proportion of immigrants is significantly related to smaller families and larger class sizes. These coefficients not only contradict the direction of the selection, but they also contradict the direction of the same variable which was significant in column two but with the opposite sign. That is, four of the five significant coefficients out of 64 are contradicted within their own sample and across samples.

Overall, there does not appear to be a consistent or significant relationship between the observable characteristics of native students and the percentage of immigrants in $5^{\text {th }}$ grade, 
once the number of total immigrants in grades 4 to 6 is limited to a narrow range. As such, the samples appear to be balanced on the observable characteristics of the students and schools, and therefore, provide a unique opportunity to exploit variation in the concentration of immigrants in $5^{\text {th }}$ grade in order to identify the effect of new immigrants on their peers.

\section{Basic Results}

Using the identification strategy and the regression specification described above, Table 4 presents the basic estimates of the long-run effects of immigrants on the high school achievements of native Israeli students. Each entry in the table represents the coefficient estimate from a separate regression on the treatment variable (the percentage of immigrant children out of all $5^{\text {th }}$ graders), for the three high school outcomes of interest: the quality of high school attended (measured by the average matriculation rate in the school between 1996 and 1998), the probability of dropping out before completing $12^{\text {th }}$ grade, and the probability of receiving a matriculation diploma at the end of high school.

The estimates reported in the first panel of the table are from regressions that include only the treatment variable and the flexible control function (the number of immigrants in grades 4 to 6 and its square, the number of children in grade 5 and its square, and the interaction between these two variables). The eight first columns in the table correspond to the eight samples used in Table 3 for the balancing tests. We should note that the sample size in each of the columns includes only native Israeli pupils, and therefore, it is identical to the sample size reported in each of the columns of Table 3 , respectively. The average $5^{\text {th }}$ grade cohort size is about $60-70$ students, with six to seven recent immigrants. The implied average proportion of recent immigrants in the $5^{\text {th }}$ grade varies from 5 to 20 percent in the eight samples.

Many of the reported point estimates in the first panel of Table 4 are small with large estimated standard errors, indicating that they are not statistically different from zero. 
However, the pattern of signs consistently points in the direction of an adverse effect of immigrants on natives' high school outcomes. Almost all of the estimates obtained from the 16-20, 26-30 and 31-35 samples are significant at the 5 or 10 percent level. In the last two columns of the table, we present two alternative estimates of the treatment effect, and their associated t-statistics. Column 9 is simply the weighted average of the eight within-interval treatment effects, whereas column 10 presents the treatment effect obtained from the fully interacted model discussed in Section 3. The point estimates for the effect of immigrant concentration on the high school quality and on the matriculation rate are remarkably similar according to the two methods, while the effect on the dropout rate is larger in the fully interacted model. The estimates indicate that immigrant concentration in elementary school has a negative effect on the quality of high school attended and on high school matriculation rates, and a positive effect on the dropout rate. However, all the coefficients are small and statistical significance is marginal at most. The point estimates imply that a 10 point increase in the percentage immigrants in grade 5 lowers the matriculation rate of the high school attended by $1.1-1.3$ percentage points, raises the dropout rate by $0.5-1.0$ percentage points, and lowers the individual matriculation rate by $1.8-1.9$ percentage points.

When background characteristics of the student (father's and mother's schooling, number of siblings, ethnic origin) and of the elementary school (test scores and socio-economic index in 1991, a dummy for religious elementary school, class size in 1994) are added as controls to the regressions, in the lower panel of the table, almost all of the estimates of the treatment remain statistically insignificant. However, six of the estimates of the effect of the percentage of immigrants on the matriculation rate are negative and their weighted average is negative and just marginally insignificant. The average estimated effect is relatively small: a 10 percent increase in the proportion of immigrants in the class induces a 1.4-1.5 percentage point decline in the school average matriculation rate. The fact that the estimated effect does not change very much as a result of adding the background characteristics as controls may be 
interpreted as additional evidence that the treatment and control samples are relatively balanced in these observable measures, once one conditions on grade size and number of immigrants in grades 4 to 6 . Overall, the evidence in Table 4 suggests that the effect of immigrants in $5^{\text {th }}$ grade on the high school achievements of natives is likely to be negative, but not very significant statistically or in magnitude.

\section{Heterogeneous Effects}

Up to now, we have only attempted to estimate the effect of immigrants on the overall population of natives. However, the effect of immigrants on the outcomes of natives may vary with the background characteristics of the native student. We now examine the effect of immigrants on disadvantaged native students who are possibly more likely to be affected by the presence of immigrants in the classroom. ${ }^{9}$ We use two measures to identify disadvantaged native students. The first is based on parental schooling, while the second is based on ethnic background. In the next section, we investigate whether there are differential effects on the outcomes of natives when the treatment variable is defined as the percentage of disadvantaged immigrants in the $5^{\text {th }}$ grade.

Table 5 presents the estimates when each of the basic eight samples was stratified by the mother's years of schooling, below or above 10. Panel A in the table presents the results for natives with less educated mothers and panel B presents the results obtained for the natives with more-educated mothers. The point estimates for each sub-sample are generally imprecise, but the weighted average estimates for the effect of immigrant concentration on the dropout rate and the matriculation rate for natives with less-educated mothers are significantly different from zero. Also, the estimated effect in panel A is relatively large: a 10 percent increase in the proportion of immigrants leads to a 2 percentage points increase in the drop out rate (versus a mean of 8 percent) and to a 4.5 percentage point reduction in the matriculation 
rate (relative to a mean of 58 percent in the sample). The proportion of immigrants in the classroom has no effect on the drop-out rate of children with more-educated mothers and the effect on matriculation rates is one-third the size of the coefficient found with the sample of natives with less-educated mothers. The effect on the quality of high school attended is negative and more statistically significant with the more advantaged sample, but the magnitudes of the coefficients are very similar for both advantaged and disadvantaged natives. Overall, the weighted-average results point to a stronger effect of the immigrants on the disadvantaged natives, and similar results are found in the fully interacted model in the last column.

An alternative way to identify disadvantaged students is to stratify the sample by ethnic origin. Israeli society is quite clearly divided along ethnic lines in terms of socio-economic status. For example, Israeli children of Asia-Africa origin (defined by themselves or their parents being born in an African or Asian country) have the lowest average background characteristics (parental schooling, income and other social and family attributes). Table 6 presents estimates based on a sample that includes children whose ethnic origin is Asia-Africa (panel A) and estimates from a sample of all other Israeli children (Panel B). ${ }^{10}$ The results presented in the first panel show clearly that native Israeli students from Africa-Asia origin experience significantly lower human capital outcomes as the proportion of immigrants in the classroom increases. The most dramatic effect is on the matriculation rate: the estimated coefficients across the row (the row for the matriculation rate in Panel A) are all negative, three of them are individually significant and the weighted average of the eight estimates is 0.0045 with a t-statistic of 3.5 . This point estimate implies that a 10 percentage point increase in the proportion of immigrants reduces the matriculation rate of the Africa-Asia ethnic group

\footnotetext{
${ }^{9}$ A number of papers have shown that the outcomes of disadvantaged students are more responsive to changes in school resources (Angrist and Lavy, 1999; Krueger, 1999; Hoxby, 2000b; Jepsen and Rivkin, 2002).

${ }^{10}$ Children in our sample belong to the 1983-1984 cohort, meaning that their parents would typically have been born between 1950 and 1965. Therefore, our ethnic origin indicator is likely to identify quite accurately children of parents who immigrated from North African countries in the later 1950s and 1960s.
} 
by 4.5 percent, an effect that amounts to around 15 percent of the respective mean. In contrast to this relatively large effect for native students of Asia-Africa origin, there is no significant effect using the sample of all the other Israeli students. This pattern of results is also seen in the last column using the fully interacted model.

In Table 7, we define students as disadvantaged if they have both a low-educated mother and they are of Asia-Africa origin. Despite the fact that the number of students in this intersection is relatively small, we still find large and significant effects of immigrant concentration on high school achievements. For this very disadvantaged group, a ten percent increase in immigrant concentration raises the dropout rate by 2.0-3.2 percentage points, and lowers the matriculation rate by 4.0-5.6 percentage points, while there is essentially no effect on high school quality. These effects are larger than those found in either of the previous two tables.

Table 8 performs the analysis separately for males and females. The results suggest that female students are negatively affected by the presence of immigrants in terms of their dropout rate and matriculation rate, but no significant effect is detected for males using these outcomes. However, the males seem to experience a large negative effect when it comes to the quality of the high school attended relative to females.

\section{Comparison with OLS}

It is now natural to ask how our results would have changed had we adopted a more naïve methodology. We explore this issue in Table 9. The last two columns of the table reproduce the estimates from Tables 4-6 in the fully interacted model and in the "weighted average" model, for the full sample (Panel A), for students with low-educated mothers (Panel B), and for students of Asia-Africa origin (Panel C). Column 1 presents the estimates and associated t-statistics from a simple bivariate regression of the high school outcome variables on percentage immigrants in grade 5. Not surprisingly, the point estimates in this specification 
are substantially larger than those obtained with the quasi-experimental approach, reflecting the non-random selection of immigrants across schools. In columns 2 through 5, we progressively add more control variables to assess how the estimates vary and how they compare to the ones obtained in the quasi-experimental approach. In columns 2 and 3, we add individual level and traditional school level control variables (a religious dummy, average class size in 1994, school test scores and socioeconomic index in 1991). In column 4 we add linearly the two key conditioning variables, whose inclusion stems directly from the structure of the assignment mechanism discussed in Section 3 (i.e., the number of children in grade 5 and the number of immigrant children in grades 4 to 6 ). In column 5 , the key conditioning variables are included together with their squares and their interaction. This is the same flexible polynomial control function used in the previous tables.

The table reveals that inclusion of the basic individual and school-level control variables takes care of a large fraction of the selection bias, lowering substantially all of the coefficients and t-statistics. However, we also note that in a number of specifications and samples, there is a marked difference between the naïve OLS estimates of columns 2 and 3, and the quasiexperimental estimates that take into account the structure of the assignment mechanism. For example, in both the full sample and the two sub-samples, the naïve OLS coefficient for the quality of high school attended is small and insignificant, while it becomes substantially larger and statistically significant in the quasi-experimental specifications. A similar pattern emerges for the effect of the treatment on high school matriculation rates, but only in the disadvantaged samples: a 10 percent increase in immigrant concentration lowers matriculation rates by 1.3 percent ( 2.3 percent) in the low-education (Asia-Africa) sub-sample according to the naïve estimates, but the effect increases to $2.5-4.5$ percent (3.4-4.5 percent) when we control for the number of immigrants in the school. It appears that carefully taking into account the mechanism generating variation in immigrant concentration across schools 
generates somewhat larger estimates of the treatment effect, which we believe to be more credible than those obtained in a more naïve specification.

Overall, the results in this section show a clear pattern of stronger and more negative effects of immigrants on the human capital outcomes of natives coming from a more disadvantaged background. In the next section, we probe further into the above finding that disadvantaged native students experience large and significant peer effects on their human capital outcomes by exploiting the unique episode generated by the mass exodus of extremely disadvantaged immigrants from Ethiopia in May 1991.

\section{Peer Effects in Schools that Absorbed Immigrants from Ethiopia}

In May 1991, fifteen thousand Ethiopian Jews were brought to Israel in an overnight airlift and sorted in a hurried and haphazard fashion to absorption centers across the country. This operation, known as Operation Solomon, created variation in the quality of schools faced by Ethiopian children, which was uncorrelated with the family background characteristics of each immigrant child. This natural experiment was used by Gould, Lavy, and Paserman (2004) to show that variation in elementary school quality had a significant impact on the achievements of Ethiopian immigrant children in high school. In contrast, this section examines whether the presence of Ethiopian children in the classroom in $5^{\text {th }}$ grade had an impact the achievements of native Israeli students in high school. This empirical context allows us to examine the presence and dimension of peer effects of immigrants on natives in a situation where the newcomers are from a much poorer social and economic background relative to the recipient group. This represents a sharp contrast to the experiment exploited in the previous section in which the immigrants (mostly from the former Soviet Union) were equally or even more educated than the average adult native Israelis, even though their economic status was inferior. 
We adopt the same identification strategy we used in the previous section when analyzing peer effects for all immigrants. Namely, to identify the causal effect of Ethiopian immigrants on their peers, we exploit random variation in the number of immigrants across grades within the same school. The identifying assumption is again that the proportion of Ethiopians in $5^{\text {th }}$ grade, conditioned on a given number of Ethiopian students in $4^{\text {th }}$ to $6^{\text {th }}$ grade, is determined exogenously by random factors such as variation in the dates of birth among the pool of immigrant children in a school district.

Table 10 presents balancing tests for four samples defined by narrow ranges for the total number of May 1991 Ethiopian immigrants between grades 4 and 6. We restrict attention to schools with no more than 20 Ethiopian immigrant children, as the data becomes extremely sparse beyond this cut-off point. The treatment is now the percentage of these Ethiopian students in the school's $5^{\text {th }}$ grade. The summary statistics at the bottom of the table indicate that as the number of Ethiopian immigrants in grades 4 to 6 increases, so does the average number and percentage of Ethiopians in grade 5. For example, schools with 1 to 5 Ethiopians in grades 4 to 6 had on average 2.3 percent Ethiopians in grade 5, whereas in schools with 16 to 20 Ethiopians the percentage rises to 13.41 .

The first three columns of Table 10 show insignificant coefficients for the relationships between parental education levels of native students and the percentage of May 1991 Ethiopian immigrants in their $5^{\text {th }}$ grade class. Of the 24 coefficients presented in these three columns only one, the coefficient on class size in the third column, is significant at the 5 percent level, while the second highest t-statistic is 1.52. All the point estimates in these three columns are also very small, another indication that these samples are balanced, and do not reveal any systematic differences related to the proportion of May 1991 Ethiopian immigrants. However, some systematic differences according to the proportion of Ethiopian students are evident in column 4 of Table 10. In particular, significant coefficients are found for mother's and father's years of schooling and for the socioeconomic index in 1991. These results 
indicate that schools in this sample that absorbed more May 1991 Ethiopian students in $5^{\text {th }}$ grade tended to have native students from less-educated families and from a weaker socioeconomic background. However, it is unlikely that these differences reflect selection, because this should also show up in differences in number of siblings and in average test scores of the school as well. Since no such differences are observed (in fact, some of the signs reflect positive selection) and since this sample is very small, including only 16 schools, we are therefore inclined to relate to these minor differences as not representing systematic differences due to variation in the proportion of May 1991 Ethiopian immigrants in $5^{\text {th }}$ grade. In any case, some caution should be exercised in interpreting the results in the last column.

Table 11 presents the analysis of the native outcomes in high school using the treatment defined as the percentage Ethiopians in the $5^{\text {th }}$ grade. The first panel presents the results for all native children. The first column reveals that when the proportion of Ethiopian students is small, their presence does not affect the outcomes of native students. However, the coefficients in the next three columns show an adverse effect on natives in schools where the fraction of Ethiopian immigrants was relatively high. For example, the coefficients in columns 2-4 in Panel A are all large and statistically significant for the matriculation rate. These results suggest that peer effects seem to exist only at higher intensity levels of treatment. Taking the weighted average of the effects does not yield precise estimates, mostly because the weighted average is dominated by the first sample where the intensity of the treatment is weak and the estimated effect is minor. In fact, the weighted average of the effect on matriculation rates in the last three columns is -0.011 (t-statistic of 5.29). Significant negative results are also obtained using the fully interacted model in the last column of the table.

Panel B of Table 11 presents the results for the sample of native children with low mother's year of schooling (below 10 years) drawn for each of the four basic samples. These results also show a significant negative peer effect on the matriculation rate, and the 
magnitudes of the coefficients are generally larger than the coefficients using the sample of all native students. For example, in the second column, the effect for the low education sample is more than twice as large as for the whole sample (-0.016 versus -0.007$)$. This result is fully consistent with the results presented in Tables 5-7 where we found the peer effect of immigrants to be stronger and more precisely estimated among native students from low educated families. It is also important to note that the "no adverse peer effect" result seen at low levels of treatment intensity (low proportion of Ethiopian students in class) is evident also in the second panel. In fact, in schools with 1 to 5 Ethiopian immigrants, the results appear to be reversed: the proportion of Ethiopian immigrants lowers native Israelis' drop out rates (the effect is significant at the 10 percent level), and it raises matriculation rates. This suggests that even the most disadvantaged students are not affected from the presence of immigrants in the classroom as long as their proportion is small.

Panel $\mathrm{C}$ in Table 11 restricts the analysis to only native students from Asia-Africa ethnic origin. The basic results are again very much in line with those presented in panel B and discussed above: relatively large and negative peer effect of Ethiopian immigrants on the matriculation probability of disadvantaged native students. However, similar to Panel B, the significant results are mainly found at higher levels of immigrant concentration (columns 2 and 3 versus column 1) and in the fully interacted model (the last column).

\section{Conclusion}

In this paper we have estimated the impact of immigrant concentration in elementary school on the high school outcomes of native Israelis, using a natural experiment generated by random variation in the distribution of immigrants across grades within a given school. Overall, we find that the percentage of immigrants in elementary school has essentially no effect on dropout rates, while it has at most a mild effect on the quality of the high school attended and on high school matriculation rates. However, splitting the sample by parents' 
years of schooling and ethnic origin reveals a consistent pattern: disadvantaged children appear more likely to have been adversely affected by a higher concentration of immigrants among their peers. Interestingly, when we define the treatment as the percentage of disadvantaged immigrants, the estimated treatment effects are even larger, particularly at high levels of treatment intensity.

Our paper represents one of the first attempts to study the consequences of natives and immigrants interacting in the same social and learning environment, while paying particular attention to issues of identification and causality. The finding that exposure to immigrants during elementary school yields detrimental effects on disadvantaged children into their high school years is a new result, given that most of the literature focuses on contemporaneous peer effects, rather than long term outcomes.

In many respects, our findings can be of general interest beyond the local Israeli context. The empirical episode we study allows us to examine how immigrants from a relatively educated and skilled background from the former Soviet republics affect the human capital outcomes of natives. The lessons learned from this analysis are becoming increasingly relevant to Western countries that are expected to absorb growing numbers of immigrants from Central and Eastern Europe.

Our findings lead to at least two policy implications. First, any negative effect that arises from integrating immigrants with native students in regular schools is mitigated when their proportion is relatively small, suggesting that it is beneficial to spread the immigrants in as many schools as possible. Second, absorbing immigrants in schools may require additional resources to offset the crowding out of resources or the negative peer effects. These policy lessons are equally relevant in an environment of highly educated immigrants since their economic and language inferiority may put them at a disadvantage relative to native students.

Our finding may also have implications for income inequality. The most important dividing line in schooling in the US is high school completion. In Israel and in many 
European countries, the crucial threshold is passing the matriculation exams, which opens the door to a college education. Angrist and Lavy (2004) estimated the returns to a year of schooling in Israel at about 8.3 percent, while holders of the Israeli matriculation certificate earn a further 24 percent. The returns to the matriculation certificate partly reflect the increased likelihood of higher education. But even in a sample limited to those with exactly 12 years of schooling, holders of the matriculation certificate earn 13 percent more. The effect of immigrants on the matriculation outcomes of natives may therefore have severe implications for the income of disadvantaged natives as well as for income inequality. 


\section{References}

Altonji, Joseph G., and Card, David. "The Effects of Immigration on the Labor Market Outcomes of Less-Skilled Natives." In Immigration, Trade and Labor, edited by John M. Abowd, and Richard B. Freeman. Chicago: University of Chicago Press, 1991.

Angrist, Joshua D. and Lang, Kevin. "How Important are Classroom Peer Effects? Evidence from Boston's Metco Program.” NBER Working paper no. 9263, October 2002.

Angrist, Joshua D. and Lavy, Victor. "Using Maimonides' Rule to Estimate the Effect of Class Size on Scholastic Achievement." Quarterly Journal of Economics, 114(2), May 1999, pages 533-75.

Angrist, Joshua D. and Lavy, Victor "The Effect of High Stakes High School Achievement Awards Evidence from a Group Randomized Trial", Draft, September, 2004.

Betts, Julian R. "Educational Crowding Out: Do Immigrants Affect the Educational Attainment of American Minorities?", in Daniel S. Hamermesh and Frank D. Bean (Eds.), Help or Hindrance? The Economic Implications of Immigration for AfricanAmericans, New York: Russell Sage Foundation, 1998.

Betts, Julian R. and Fairlie, Robert W. "Does Immigration Induce 'Native Flight' from Public Schools into Private Schools." Journal of Public Economics, 87(5-6), May 2003, pp. 987-1012.

Borjas, George J. "Do Foreign Students Crowd Out Native Students from Graduate Programs?" NBER Working Paper 10349, 2004.

Borjas, George J., Freeman, Richard B, and Katz, Lawrence. "Searching for the Effect of Immigration on the Labor Market", American Economic Review, 86(2), May 1996, pp. 246-251.

Borjas, George J. "The Labor Demand Curve Is Downward Sloping: Reexamining the Impact of Immigration on the Labor Market." Quarterly Journal of Economics, November 2003.

Card, David. "The Impact of the Mariel Boatlift on the Miami Labor Market." Industrial and Labor Relations Review, 43(1), January 1990, pp. 245-257.

Card, David. "Immigrant Inflows, Native Outflows, and the Local Labor Market Impacts of Higher Immigration.” Journal of Labor Economics, 19(1), January 2001, pp. 22-64.

Cohen-Goldner, Sarit and Paserman, M. Daniele. "Mass Migration to Israel and Natives' Transitions from Employment." Mimeo., Hebrew University, 2004a.

Cohen-Goldner, Sarit and Paserman, M. Daniele. "The Dynamic Impact of Immigration on Natives' Labor Market Outcomes: Evidence from Israel.” Mimeo., Hebrew University, 2004b.

Edin, Per-Anders, Peter Fredriksson, and Olof Åslund, "Ethnic Enclaves and the Economic Success of Immigrants - Evidence from a Natural Experiment," Quarterly Journal of Economics, CXVIII (2003), 329-357.

Friedberg, Rachel M. "The Impact of Mass Migration on the Israeli Labor Market." Quarterly Journal of Economics, 116(4), November 2001, pp. 1373-1408.

Gould, Eric D.; Lavy Victor and Paserman, M. Daniele. "Immigrating to Opportunity: Estimating the Effects of School Quality Using a Natural Experiment on Ethiopians in Israel." Quarterly Journal of Economics, May 2004.

Hanushek, Eric, John F. Kain, and Steven G. Rivkin, "New Evidence About Brown V. Board of Education: The Complex Effects of School Racial Composition on Achievement," NBER Working Paper No. 8741, 2002.

Hoxby, Caroline M. "Do Immigrants Crowd Disadvantaged American Natives Out of Higher Education?" in Daniel S. Hamermesh and Frank D. Bean (Eds.), Help or Hindrance? 
The Economic Implications of Immigration for African Americans. New York: Russell Sage Foundation, 1998.

Hoxby, Caroline M. "Peer Effects in the Classroom: Learning from Gender and Race Variation.” NBER Working Paper No. 7867, August 2000a.

Hoxby, Caroline M. "The Effects of Class Size on Student Achievement: New Evidence from Population Variation." Quarterly Journal of Economics; 115(4), November 2000b, pages $1239-85$.

Jacob, Brian A., "Public Housing, Housing Vouchers and Student Achievement: Evidence from Public Housing Demolitions in Chicago," NBER Working Paper No. 9652, 2003.

Jepsen, Christopher, and Steven Rivkin. "What is the Tradeoff between Smaller Classes and Teacher Quality?” NBER Working Paper No. 9205, September 2002.

Katz, Lawrence F., Jeffrey R. Kling, and Jeffrey B. Liebman, "Moving to Opportunity in Boston: Early Results from a Randomized Mobility Experiment," Quarterly Journal of Economics CXVI (2001), 607-654.

Krueger, Alan B. "Experimental Estimates of Education Production Functions", Quarterly Journal of Economics, CXIV (1999), 497-532.

LaLonde, Robert and Topel, Robert. "Labor Market Adjustments to Increased Immigration." In Immigration, Trade and Labor, edited by John M. Abowd, and Richard B. Freeman. Chicago: University of Chicago Press, 1991.

Oreopoulos, Philip, "The Long-Run Consequences of Living in a Poor Neighborhood," Quarterly Journal of Economics, CXVIII (2003), forthcoming.

Sacerdote, Bruce, "Peer Effects with Random Assignment: Results for Dartmouth Roommates," Quarterly Journal of Economics, CXVI (2001), 681-704.

Weinberg, Bruce A., Patricia B. Reagan, and Jeffrey J. Yankow, "Do Neighborhoods Affect Hours Worked: Evidence from Longitudinal Data," Journal of Labor Economics, XXII (2004), forthcoming.

Zimmerman, David J., "Peer Effects in Academic Outcomes: Evidence from a Natural Experiment," Review of Economics and Statistics, LXXXV (2003), 9-23. 
Table 1: Background Characteristics of Immigrants and Natives

\begin{tabular}{cccccc}
\hline A: Ministry of Education data: & \multicolumn{4}{c}{ Immigrants from: } & \multirow{2}{*}{\begin{tabular}{c} 
All \\
\cline { 3 - 5 }
\end{tabular}} \\
\cline { 3 - 5 } & $\begin{array}{c}\text { Immigrants } \\
\text { Former Soviet } \\
\text { Union }\end{array}$ & Ethiopia & Other & Native Israelis \\
\hline $\begin{array}{c}\text { Father's years of } \\
\text { schooling }\end{array}$ & 11.45 & 13.04 & 1.80 & 14.21 & 12.03 \\
$\begin{array}{c}\text { Mother's years } \\
\text { of schooling }\end{array}$ & $15.49)$ & $(3.62)$ & $(3.30)$ & $(4.46)$ & $(3.56)$ \\
$\begin{array}{c}\text { Number of } \\
\text { siblings }\end{array}$ & $(5.31)$ & $(3.26)$ & $(2.90)$ & $(3.70)$ & 12.05 \\
$\begin{array}{c}\text { Number of } \\
\text { children }\end{array}$ & $(1.54$ & 1.10 & 4.28 & 1.98 & $2.41)$ \\
\hline
\end{tabular}

\begin{tabular}{|c|c|c|c|c|c|}
\hline \multicolumn{5}{|c|}{ B: Census 1995 data } & \multirow[b]{3}{*}{ Native Israelis } \\
\hline & \multirow{2}{*}{$\begin{array}{c}\text { All } \\
\text { Immigrants }\end{array}$} & \multicolumn{3}{|c|}{ Immigrants from: } & \\
\hline & & $\begin{array}{c}\text { Former Soviet } \\
\text { Union }\end{array}$ & Ethiopia & Other & \\
\hline $\begin{array}{c}\text { Father's years of } \\
\text { schooling }\end{array}$ & $\begin{array}{l}12.69 \\
(4.50)\end{array}$ & $\begin{array}{l}13.51 \\
(3.20)\end{array}$ & $\begin{array}{c}2.57 \\
(4.61)\end{array}$ & $\begin{array}{l}13.50 \\
(4.32)\end{array}$ & $\begin{array}{l}11.67 \\
(3.83)\end{array}$ \\
\hline $\begin{array}{l}\text { Mother's years } \\
\text { of schooling }\end{array}$ & $\begin{array}{l}12.53 \\
(4.52)\end{array}$ & $\begin{array}{l}13.45 \\
(3.09)\end{array}$ & $\begin{array}{c}1.92 \\
(4.20)\end{array}$ & $\begin{array}{l}13.40 \\
(3.95)\end{array}$ & $\begin{array}{l}11.59 \\
(3.98)\end{array}$ \\
\hline $\begin{array}{l}\text { Female headed } \\
\text { household }\end{array}$ & $\begin{array}{c}0.176 \\
(0.381)\end{array}$ & $\begin{array}{c}0.179 \\
(0.383)\end{array}$ & $\begin{array}{c}0.248 \\
(0.432)\end{array}$ & $\begin{array}{c}0.093 \\
(0.290)\end{array}$ & $\begin{array}{c}0.085 \\
(0.278)\end{array}$ \\
\hline $\begin{array}{c}\text { Home } \\
\text { ownership }\end{array}$ & $\begin{array}{c}0.533 \\
(0.499)\end{array}$ & $\begin{array}{c}0.561 \\
(0.496)\end{array}$ & $\begin{array}{c}0.482 \\
(0.500)\end{array}$ & $\begin{array}{c}0.338 \\
(0.473)\end{array}$ & $\begin{array}{c}0.693 \\
(0.461)\end{array}$ \\
\hline $\begin{array}{l}\text { Household head } \\
\text { unemployed }\end{array}$ & $\begin{array}{c}0.071 \\
(0.256)\end{array}$ & $\begin{array}{c}0.067 \\
(0.252)\end{array}$ & $\begin{array}{c}0.096 \\
(0.295)\end{array}$ & $\begin{array}{c}0.086 \\
(0.281)\end{array}$ & $\begin{array}{c}0.037 \\
(0.189)\end{array}$ \\
\hline $\begin{array}{l}\text { Household } \\
\text { monthly income }\end{array}$ & $\begin{array}{c}3895.85 \\
(3911.46)\end{array}$ & $\begin{array}{c}4258.76 \\
(3738.91)\end{array}$ & $\begin{array}{c}751.01 \\
(1184.43)\end{array}$ & $\begin{array}{c}3497.91 \\
(5371.44)\end{array}$ & $\begin{array}{c}5899.36 \\
(6963.88)\end{array}$ \\
\hline $\begin{array}{l}\text { Number of } \\
\text { households }\end{array}$ & 8,910 & 7,321 & 737 & 852 & 68,725 \\
\hline
\end{tabular}

Notes: The Ministry of Education sample includes the universe of children enrolled in $5^{\text {th }}$ grade during the 19931994 school year. The Census data includes all households with at least one child between the ages of 8 and 12 in 1995. 
Table 2: Summary Statistics

\begin{tabular}{|c|c|c|c|c|}
\hline & \multicolumn{4}{|c|}{ Number of immigrants in grades 4 through 6} \\
\hline & 1-10 & $11-20$ & 21-30 & $31-40$ \\
\hline Number of schools & 271 & 144 & 164 & 124 \\
\hline $\begin{array}{l}\text { Total number of children in } \\
\text { grade } 5\end{array}$ & 13,014 & 13,707 & 9,943 & 7,329 \\
\hline $\begin{array}{l}\text { Average number of children } \\
\text { in grade } 5\end{array}$ & 66.23 & 76.00 & 83.47 & 87.24 \\
\hline $\begin{array}{l}\text { Average percentage } \\
\text { immigrants in grade } 5\end{array}$ & 4.04 & 8.00 & 11.51 & 15.47 \\
\hline \multicolumn{5}{|l|}{$\begin{array}{l}\text { Peer characteristics } \\
\text { (non-immigrants) }\end{array}$} \\
\hline Father's years of schooling & $\begin{array}{l}12.58 \\
(3.65)\end{array}$ & $\begin{array}{l}12.19 \\
(3.52)\end{array}$ & $\begin{array}{l}11.93 \\
(3.30)\end{array}$ & $\begin{array}{l}11.86 \\
(3.32)\end{array}$ \\
\hline Mother's years of schooling & $\begin{array}{l}12.62 \\
(3.46)\end{array}$ & $\begin{array}{l}12.18 \\
(3.36)\end{array}$ & $\begin{array}{l}12.00 \\
(3.12)\end{array}$ & $\begin{array}{l}11.79 \\
(3.27)\end{array}$ \\
\hline Number of siblings & $\begin{array}{c}2.43 \\
(1.69)\end{array}$ & $\begin{array}{c}2.46 \\
(1.54)\end{array}$ & $\begin{array}{c}2.38 \\
(1.54)\end{array}$ & $\begin{array}{c}2.33 \\
(1.43)\end{array}$ \\
\hline Fraction Asia-Africa & $\begin{array}{c}0.243 \\
(0.429)\end{array}$ & $\begin{array}{c}0.293 \\
(0.455)\end{array}$ & $\begin{array}{l}0.318 \\
(0.466)\end{array}$ & $\begin{array}{c}0.314 \\
(0.464)\end{array}$ \\
\hline Class Size & $\begin{array}{l}30.06 \\
(6.04)\end{array}$ & $\begin{array}{l}31.05 \\
(5.74)\end{array}$ & $\begin{array}{l}32.47 \\
(5.17)\end{array}$ & $\begin{array}{l}32.96 \\
(5.45)\end{array}$ \\
\hline \multicolumn{5}{|l|}{ School characteristics } \\
\hline $\begin{array}{c}\text { Standardized Math } \\
\text { Score in } 1991\end{array}$ & $\begin{array}{c}0.342 \\
(0.775)\end{array}$ & $\begin{array}{c}0.155 \\
(0.842)\end{array}$ & $\begin{array}{c}0.109 \\
(0.806)\end{array}$ & $\begin{array}{c}0.087 \\
(0.820)\end{array}$ \\
\hline $\begin{array}{l}\text { Standardized Verbal } \\
\text { Score in } 1991\end{array}$ & $\begin{array}{c}0.401 \\
(0.773)\end{array}$ & $\begin{array}{c}0.131 \\
(0.806)\end{array}$ & $\begin{array}{c}0.014 \\
(0.743)\end{array}$ & $\begin{array}{l}-0.009 \\
(0.819)\end{array}$ \\
\hline $\begin{array}{c}\text { Socioeconomic Index } \\
\text { in } 1991\end{array}$ & $\begin{array}{c}0.388 \\
(0.759)\end{array}$ & $\begin{array}{c}0.181 \\
(0.824)\end{array}$ & $\begin{array}{l}0.149 \\
(0.812)\end{array}$ & $\begin{array}{c}0.109 \\
(0.831)\end{array}$ \\
\hline $\begin{array}{l}\text { Income per capita in school } \\
\text { locality in } 1991\end{array}$ & 978.50 & 892.69 & 891.53 & 897.24 \\
\hline $\begin{array}{l}\text { Unemployment rate in } \\
\text { school locality in } 1991\end{array}$ & 2.94 & 1.63 & 1.44 & 1.45 \\
\hline $\begin{array}{l}\text { Welfare recipiency rate in } \\
\text { school locality in } 1991\end{array}$ & 23.06 & 29.19 & 30.77 & 29.19 \\
\hline $\begin{array}{l}\text { High school matriculation } \\
\text { rate in school locality in } \\
1991\end{array}$ & 47.96 & 46.63 & 46.49 & 46.69 \\
\hline \multicolumn{5}{|l|}{ Outcome Variables } \\
\hline $\begin{array}{l}\text { Quality of high school } \\
\text { attended }\end{array}$ & $\begin{array}{c}0.660 \\
(0.214)\end{array}$ & $\begin{array}{c}0.638 \\
(0.223)\end{array}$ & $\begin{array}{c}0.623 \\
(0.230)\end{array}$ & $\begin{array}{c}0.617 \\
(0.229)\end{array}$ \\
\hline $\begin{array}{l}\text { Fraction dropping out } \\
\text { before completing } 12^{\text {th }} \\
\text { grade }\end{array}$ & $\begin{array}{c}0.078 \\
(0.268)\end{array}$ & $\begin{array}{c}0.092 \\
(0.289)\end{array}$ & $\begin{array}{c}0.094 \\
(0.292)\end{array}$ & $\begin{array}{c}0.099 \\
(0.299)\end{array}$ \\
\hline $\begin{array}{l}\text { Fraction eligible for high } \\
\text { school matriculation }\end{array}$ & $\begin{array}{c}0.621 \\
(0.485)\end{array}$ & $\begin{array}{c}0.587 \\
(0.492)\end{array}$ & $\begin{array}{c}0.582 \\
(0.493)\end{array}$ & $\begin{array}{c}0.558 \\
(0.497)\end{array}$ \\
\hline
\end{tabular}

Notes: Authors' calculations based on Ministry of Education data. 
Table 3: Balancing Tests

\begin{tabular}{|c|c|c|c|c|c|c|c|c|}
\hline \multicolumn{9}{|c|}{ Number of immigrants in grades 4 to 6: } \\
\hline & 1-5 & 6-10 & 11-15 & $16-20$ & 21-25 & 26-30 & 31-35 & $36-40$ \\
\hline $\begin{array}{l}\text { Mother's years of } \\
\text { schooling }\end{array}$ & $\begin{array}{c}0.0629 \\
{[1.3489]}\end{array}$ & $\begin{array}{c}0.0012 \\
{[0.0361]}\end{array}$ & $\begin{array}{c}0.0117 \\
{[0.4163]}\end{array}$ & $\begin{array}{c}0.0069 \\
{[0.2231]}\end{array}$ & $\begin{array}{c}0.0298 \\
{[1.1584]}\end{array}$ & $\begin{array}{c}-0.0271 \\
{[-1.1779]}\end{array}$ & $\begin{array}{c}-0.0331 \\
{[-1.0622]}\end{array}$ & $\begin{array}{c}-0.0336 \\
{[-1.0103]}\end{array}$ \\
\hline $\begin{array}{l}\text { Father's years of } \\
\text { schooling }\end{array}$ & $\begin{array}{c}0.0656 \\
{[1.3065]}\end{array}$ & $\begin{array}{c}0.0040 \\
{[0.1083]}\end{array}$ & $\begin{array}{c}0.0187 \\
{[0.6837]}\end{array}$ & $\begin{array}{c}0.0007 \\
{[0.0233]}\end{array}$ & $\begin{array}{c}0.0288 \\
{[1.1206]}\end{array}$ & $\begin{array}{c}-0.0382 \\
{[-1.5967]}\end{array}$ & $\begin{array}{c}-0.0283 \\
{[-0.7903]}\end{array}$ & $\begin{array}{c}-0.0556 \\
{[-1.5909]}\end{array}$ \\
\hline $\begin{array}{l}\text { Number of } \\
\text { Siblings }\end{array}$ & $\begin{array}{l}-0.0039 \\
{[-0.1256]}\end{array}$ & $\begin{array}{c}0.0380 \\
{[2.2346]}\end{array}$ & $\begin{array}{l}-0.0318 \\
{[-2.1248]}\end{array}$ & $\begin{array}{c}0.0195 \\
{[1.2789]}\end{array}$ & $\begin{array}{c}-0.0117 \\
{[-0.6016]}\end{array}$ & $\begin{array}{c}0.0217 \\
{[1.4417]}\end{array}$ & $\begin{array}{c}0.0123 \\
{[0.5703]}\end{array}$ & $\begin{array}{c}0.0049 \\
{[0.2733]}\end{array}$ \\
\hline $\begin{array}{l}\text { Fraction } \\
\text { Asia-Africa }\end{array}$ & $\begin{array}{c}-0.0013 \\
{[-0.3034]}\end{array}$ & $\begin{array}{c}-0.0003 \\
{[-0.1093]}\end{array}$ & $\begin{array}{l}-0.0027 \\
{[-0.8887]}\end{array}$ & $\begin{array}{c}0.0037 \\
{[1.1824]}\end{array}$ & $\begin{array}{c}-0.0001 \\
{[-0.0167]}\end{array}$ & $\begin{array}{c}0.0021 \\
{[0.7134]}\end{array}$ & $\begin{array}{c}-0.0000 \\
{[-0.0075]}\end{array}$ & $\begin{array}{c}-0.0077 \\
{[-2.1873]}\end{array}$ \\
\hline $\begin{array}{l}\text { Standardized math score } \\
\text { in } 1991\end{array}$ & $\begin{array}{c}0.0095 \\
{[0.4521]}\end{array}$ & $\begin{array}{c}-0.0155 \\
{[-0.8047]}\end{array}$ & $\begin{array}{l}-0.0219 \\
{[-1.1500]}\end{array}$ & $\begin{array}{c}-0.0161 \\
{[-1.1771]}\end{array}$ & $\begin{array}{c}0.0121 \\
{[0.6949]}\end{array}$ & $\begin{array}{c}-0.0035 \\
{[-0.1869]}\end{array}$ & $\begin{array}{c}-0.0201 \\
{[-1.1266]}\end{array}$ & $\begin{array}{c}0.0071 \\
{[0.3676]}\end{array}$ \\
\hline $\begin{array}{l}\text { Standardized verbal } \\
\text { score in } 1991\end{array}$ & $\begin{array}{c}0.0140 \\
{[0.6283]}\end{array}$ & $\begin{array}{c}-0.0101 \\
{[-0.5539]}\end{array}$ & $\begin{array}{l}0.0046 \\
{[0.2258]}\end{array}$ & $\begin{array}{c}-0.0226 \\
{[-1.6172]}\end{array}$ & $\begin{array}{c}0.0035 \\
{[0.2069]}\end{array}$ & $\begin{array}{c}-0.0043 \\
{[-0.2651]}\end{array}$ & $\begin{array}{c}-0.0162 \\
{[-0.9549]}\end{array}$ & $\begin{array}{c}0.0137 \\
{[0.7370]}\end{array}$ \\
\hline $\begin{array}{l}\text { Socioeconomic index in } \\
1991\end{array}$ & $\begin{array}{c}0.0022 \\
{[0.0939]}\end{array}$ & $\begin{array}{l}-0.0202 \\
{[-1.0747]}\end{array}$ & $\begin{array}{c}0.0157 \\
{[0.8789]}\end{array}$ & $\begin{array}{l}-0.0222 \\
{[-1.6124]}\end{array}$ & $\begin{array}{l}-0.0192 \\
{[-1.0303]}\end{array}$ & $\begin{array}{l}-0.0199 \\
{[-1.0432]}\end{array}$ & $\begin{array}{l}-0.0023 \\
{[-0.1392]}\end{array}$ & $\begin{array}{c}0.0170 \\
{[0.8795]}\end{array}$ \\
\hline $\begin{array}{l}\text { Class size in } \\
1994\end{array}$ & $\begin{array}{c}-0.1516 \\
{[-1.1409]}\end{array}$ & $\begin{array}{l}-0.2140 \\
{[-2.4166]}\end{array}$ & $\begin{array}{c}0.2724 \\
{[2.7043]}\end{array}$ & $\begin{array}{c}0.0209 \\
{[0.2145]}\end{array}$ & $\begin{array}{c}0.0909 \\
{[0.8973]}\end{array}$ & $\begin{array}{c}0.0808 \\
{[0.7738]}\end{array}$ & $\begin{array}{c}0.0222 \\
{[0.2931]}\end{array}$ & $\begin{array}{c}0.0719 \\
{[0.7631]}\end{array}$ \\
\hline Number of schools & 123 & 148 & 153 & 91 & 99 & 65 & 72 & 52 \\
\hline Number of children & 5,031 & 7,983 & 8,346 & 5,361 & 5,857 & 4,086 & 4,159 & 3,170 \\
\hline $\begin{array}{l}\text { Average number of } \\
\text { children in } 5^{\text {th }} \text { grade }\end{array}$ & 42.20 & 57.38 & 59.46 & 66.34 & 67.85 & 73.17 & 69.50 & 74.13 \\
\hline $\begin{array}{l}\text { Average number of } \\
\text { immigrants in } 5^{\text {th }} \text { grade }\end{array}$ & 1.04 & 3.06 & 4.39 & 6.56 & 7.59 & 9.65 & 11.14 & 12.40 \\
\hline $\begin{array}{l}\text { Average Percentage } \\
\text { Immigrants in } 5^{\text {th }} \text { grade }\end{array}$ & 3.48 & 6.97 & 9.05 & 12.19 & 13.35 & 14.93 & 19.04 & 20.09 \\
\hline $\begin{array}{l}\text { Standard deviation of } \% \\
\text { Immigrants in } 5^{\text {th }} \text { grade }\end{array}$ & 4.73 & 5.84 & 5.98 & 9.70 & 7.89 & 7.75 & 9.88 & 11.18 \\
\hline
\end{tabular}

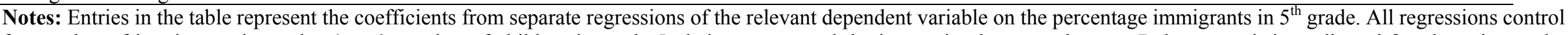

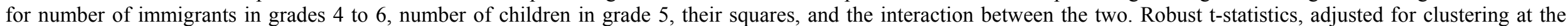
school level, in brackets. 
Table 4: Outcomes for Native Israelis

Treatment: Percentage immigrants in grade 5

Number of immigrants in grades 4 to 6:

\begin{tabular}{|c|c|c|c|c|c|c|c|c|c|c|}
\hline & \multicolumn{10}{|c|}{ Number of immigrants in grades 4 to 6 : } \\
\hline & $1-5$ & $6-10$ & $11-15$ & $16-20$ & $21-25$ & $26-30$ & $31-35$ & $36-40$ & $\begin{array}{l}\text { Weighted } \\
\text { Average }\end{array}$ & $\begin{array}{c}\text { Interacted } \\
\text { Model }\end{array}$ \\
\hline \multicolumn{11}{|l|}{$\begin{array}{l}\text { A: No Individual } \\
\text { Controls }\end{array}$} \\
\hline $\begin{array}{l}\text { Quality of high school } \\
\text { attended }\end{array}$ & $\begin{array}{c}-0.0004 \\
{[-0.1206]}\end{array}$ & $\begin{array}{c}-0.0000 \\
{[-0.0043]}\end{array}$ & $\begin{array}{c}-0.0013 \\
{[-0.5597]}\end{array}$ & $\begin{array}{c}-0.0008 \\
{[-0.3881]}\end{array}$ & $\begin{array}{c}-0.0003 \\
{[-0.1546]}\end{array}$ & $\begin{array}{c}-0.0041 \\
{[-1.7649]}\end{array}$ & $\begin{array}{c}-0.0044 \\
{[-1.8814]}\end{array}$ & $\begin{array}{c}0.0013 \\
{[0.5054]}\end{array}$ & $\begin{array}{c}-0.0011 \\
{[-1.1502]}\end{array}$ & $\begin{array}{c}-0.0013 \\
{[-1.4827]}\end{array}$ \\
\hline $\begin{array}{l}\text { Dropped out before } \\
\text { completing } 12^{\text {th }} \text { grade }\end{array}$ & $\begin{array}{c}-0.0025 \\
{[-1.1875]}\end{array}$ & $\begin{array}{c}0.0014 \\
{[0.9102]}\end{array}$ & $\begin{array}{c}-0.0005 \\
{[-0.2974]}\end{array}$ & $\begin{array}{c}0.0042 \\
{[3.0127]}\end{array}$ & $\begin{array}{c}0.0001 \\
{[0.0682]}\end{array}$ & $\begin{array}{c}0.0023 \\
{[1.7280]}\end{array}$ & $\begin{array}{c}0.0027 \\
{[1.5803]}\end{array}$ & $\begin{array}{l}-0.0030 \\
{[-1.4617]}\end{array}$ & $\begin{array}{c}0.0005 \\
{[0.8429]}\end{array}$ & $\begin{array}{c}0.0010 \\
{[1.6345]}\end{array}$ \\
\hline $\begin{array}{c}\text { Passed HS } \\
\text { matriculation exam }\end{array}$ & $\begin{array}{c}0.0033 \\
{[0.6875]}\end{array}$ & $\begin{array}{c}-0.0017 \\
{[-0.4865]}\end{array}$ & $\begin{array}{c}-0.0022 \\
{[-0.7251]}\end{array}$ & $\begin{array}{c}-0.0033 \\
{[-1.1538]}\end{array}$ & $\begin{array}{c}0.0006 \\
{[0.2581]}\end{array}$ & $\begin{array}{c}-0.0038 \\
{[-1.8040]}\end{array}$ & $\begin{array}{c}-0.0062 \\
{[-1.9465]}\end{array}$ & $\begin{array}{c}0.0026 \\
{[0.7880]}\end{array}$ & $\begin{array}{c}-0.0018 \\
{[-1.2924]}\end{array}$ & $\begin{array}{c}-0.0019 \\
{[-1.6471]}\end{array}$ \\
\hline \multicolumn{11}{|l|}{$\begin{array}{l}\text { B: With Individual } \\
\text { Controls }\end{array}$} \\
\hline $\begin{array}{l}\text { Quality of high school } \\
\text { attended }\end{array}$ & $\begin{array}{c}0.0001 \\
{[0.0340]}\end{array}$ & $\begin{array}{c}-0.0004 \\
{[-0.1643]}\end{array}$ & $\begin{array}{c}-0.0025 \\
{[-1.6935]}\end{array}$ & $\begin{array}{c}0.0004 \\
{[0.3317]}\end{array}$ & $\begin{array}{c}-0.0008 \\
{[-0.6251]}\end{array}$ & $\begin{array}{c}-0.0046 \\
{[-1.5800]}\end{array}$ & $\begin{array}{c}-0.0029 \\
{[-2.2075]}\end{array}$ & $\begin{array}{c}0.0003 \\
{[0.2029]}\end{array}$ & $\begin{array}{l}-0.0013 \\
{[1.8585]}\end{array}$ & $\begin{array}{c}-0.0012 \\
{[-2.1779]}\end{array}$ \\
\hline $\begin{array}{l}\text { Dropped out before } \\
\text { completing } 12^{\text {th }} \text { grade }\end{array}$ & $\begin{array}{c}-0.0023 \\
{[-1.2629]}\end{array}$ & $\begin{array}{c}0.0014 \\
{[0.9386]}\end{array}$ & $\begin{array}{c}0.0006 \\
{[0.4276]}\end{array}$ & $\begin{array}{c}0.0028 \\
{[2.6960]}\end{array}$ & $\begin{array}{c}0.0003 \\
{[0.2878]}\end{array}$ & $\begin{array}{c}0.0011 \\
{[1.1133]}\end{array}$ & $\begin{array}{c}0.0006 \\
{[0.4480]}\end{array}$ & $\begin{array}{l}-0.0015 \\
{[-0.9381]}\end{array}$ & $\begin{array}{c}0.0005 \\
{[0.8492]}\end{array}$ & $\begin{array}{c}0.0007 \\
{[1.3827]}\end{array}$ \\
\hline $\begin{array}{c}\text { Passed HS } \\
\text { matriculation exam }\end{array}$ & $\begin{array}{c}0.0002 \\
{[0.0438]}\end{array}$ & $\begin{array}{c}-0.0014 \\
{[-0.5359]}\end{array}$ & $\begin{array}{c}-0.0038 \\
{[-1.5762]}\end{array}$ & $\begin{array}{c}-0.0011 \\
{[-0.5927]}\end{array}$ & $\begin{array}{c}-0.0012 \\
{[-0.7159]}\end{array}$ & $\begin{array}{c}-0.0021 \\
{[-0.8740]}\end{array}$ & $\begin{array}{c}-0.0027 \\
{[-1.5703]}\end{array}$ & $\begin{array}{c}0.0017 \\
{[0.8737]}\end{array}$ & $\begin{array}{c}-0.0015 \\
{[-1.6033]}\end{array}$ & $\begin{array}{c}-0.0014 \\
{[-1.8450]}\end{array}$ \\
\hline Number of schools & 123 & 148 & 153 & 91 & 99 & 65 & 72 & 52 & 803 & 803 \\
\hline Number of children & 5,031 & 7,983 & 8,346 & 5,361 & 5,857 & 4,086 & 4,159 & 3,170 & 43,993 & 43,993 \\
\hline
\end{tabular}


Table 5: Outcomes for Native Israelis - By Mother's Education

\begin{tabular}{|c|c|c|c|c|c|c|c|c|c|c|}
\hline & \multirow{2}{*}{\multicolumn{10}{|c|}{$\begin{array}{c}\text { Treatment: Percentage immigrants in grade } 5 \\
\text { Number of immigrants in orades } 4 \text { to } 6 .\end{array}$}} \\
\hline & \multicolumn{4}{|c|}{ Number of immigrants in grades 4 to 6: } & & & & & & \\
\hline & $1-5$ & 6-10 & 11-15 & $16-20$ & $21-25$ & 26-30 & 31-35 & $36-40$ & $\begin{array}{l}\text { Weighted } \\
\text { Average }\end{array}$ & $\begin{array}{c}\text { Interacted } \\
\text { Model }\end{array}$ \\
\hline \multicolumn{11}{|l|}{$\begin{array}{c}\text { A: Mother's years of } \\
\text { schooling }<10\end{array}$} \\
\hline $\begin{array}{l}\text { Quality of high school } \\
\text { attended }\end{array}$ & $\begin{array}{l}-0.0038 \\
{[-1.1750]}\end{array}$ & $\begin{array}{c}-0.0004 \\
{[-0.1572]}\end{array}$ & $\begin{array}{c}-0.0018 \\
{[-0.7511]}\end{array}$ & $\begin{array}{c}0.0003 \\
{[0.1883]}\end{array}$ & $\begin{array}{c}-0.0007 \\
{[-0.3679]}\end{array}$ & $\begin{array}{c}-0.0031 \\
{[-1.0549]}\end{array}$ & $\begin{array}{c}0.0010 \\
{[0.4122]}\end{array}$ & $\begin{array}{c}0.0008 \\
{[0.3424]}\end{array}$ & $\begin{array}{c}-0.0012 \\
{[-1.2763]}\end{array}$ & $\begin{array}{c}-0.0006 \\
{[-0.7194]}\end{array}$ \\
\hline $\begin{array}{l}\text { Dropped out before } \\
\text { completing } 12^{\text {th }} \text { grade }\end{array}$ & $\begin{array}{c}0.0018 \\
{[0.3931]}\end{array}$ & $\begin{array}{l}0.0033 \\
{[1.1056]}\end{array}$ & $\begin{array}{c}0.0049 \\
{[1.6481]}\end{array}$ & $\begin{array}{c}0.0018 \\
{[0.8646]}\end{array}$ & $\begin{array}{l}0.0002 \\
{[0.0715]}\end{array}$ & $\begin{array}{c}0.0019 \\
{[0.8681]}\end{array}$ & $\begin{array}{l}-0.0004 \\
{[-0.1299]}\end{array}$ & $\begin{array}{c}-0.0035 \\
{[-1.6005]}\end{array}$ & $\begin{array}{c}0.0020 \\
{[1.6995]}\end{array}$ & $\begin{array}{c}0.0011 \\
{[1.1925]}\end{array}$ \\
\hline $\begin{array}{c}\text { Passed HS } \\
\text { matriculation exam }\end{array}$ & $\begin{array}{c}-0.0097 \\
{[-1.3098]}\end{array}$ & $\begin{array}{l}-0.0051 \\
{[-1.1874]}\end{array}$ & $\begin{array}{l}-0.0084 \\
{[-2.3503]}\end{array}$ & $\begin{array}{c}0.0015 \\
{[0.4571]}\end{array}$ & $\begin{array}{l}-0.0020 \\
{[-0.6962]}\end{array}$ & $\begin{array}{l}-0.0053 \\
{[-0.9792]}\end{array}$ & $\begin{array}{l}-0.0008 \\
{[-0.2871]}\end{array}$ & $\begin{array}{l}0.0016 \\
{[0.3848]}\end{array}$ & $\begin{array}{c}-0.0045 \\
{[-2.6166]}\end{array}$ & $\begin{array}{c}-0.0025 \\
{[-1.7764]}\end{array}$ \\
\hline Number of children & 957 & 1,361 & 1,675 & 1,060 & 1,222 & 725 & 902 & 774 & 12,549 & 12,549 \\
\hline \multicolumn{11}{|l|}{$\begin{array}{c}\text { B: Mother's years of } \\
\text { schooling } \geq 10\end{array}$} \\
\hline $\begin{array}{l}\text { Quality of high school } \\
\text { attended }\end{array}$ & $\begin{array}{c}0.0004 \\
{[0.1903]}\end{array}$ & $\begin{array}{c}-0.0006 \\
{[-0.2771]}\end{array}$ & $\begin{array}{c}-0.0031 \\
{[-2.0564]}\end{array}$ & $\begin{array}{c}-0.0000 \\
{[-0.0288]}\end{array}$ & $\begin{array}{l}-0.0011 \\
{[-0.6851]}\end{array}$ & $\begin{array}{l}-0.0039 \\
{[-1.5894]}\end{array}$ & $\begin{array}{c}-0.0036 \\
{[-2.6941]}\end{array}$ & $\begin{array}{l}-0.0003 \\
{[-0.2006]}\end{array}$ & $\begin{array}{l}-0.0016 \\
{[-2.1654]}\end{array}$ & $\begin{array}{c}-0.0016 \\
{[-2.5608]}\end{array}$ \\
\hline $\begin{array}{l}\text { Dropped out before } \\
\text { completing } 12^{\text {th }} \text { grade }\end{array}$ & $\begin{array}{l}-0.0029 \\
{[-1.5794]}\end{array}$ & $\begin{array}{c}0.0006 \\
{[0.4283]}\end{array}$ & $\begin{array}{c}-0.0004 \\
{[-0.2890]}\end{array}$ & $\begin{array}{c}0.0026 \\
{[2.6116]}\end{array}$ & $\begin{array}{l}0.0008 \\
{[0.7575]}\end{array}$ & $\begin{array}{c}0.0009 \\
{[0.7176]}\end{array}$ & $\begin{array}{c}0.0002 \\
{[0.2279]}\end{array}$ & $\begin{array}{l}-0.0008 \\
{[-0.4600]}\end{array}$ & $\begin{array}{c}0.0000 \\
{[0.0580]}\end{array}$ & $\begin{array}{c}0.0004 \\
{[0.8639]}\end{array}$ \\
\hline $\begin{array}{c}\text { Passed HS } \\
\text { matriculation exam }\end{array}$ & $\begin{array}{c}-0.0010 \\
{[-0.9639]}\end{array}$ & $\begin{array}{c}-0.0011 \\
{[-0.4546]}\end{array}$ & $\begin{array}{c}-0.0027 \\
{[-1.0486]}\end{array}$ & $\begin{array}{c}-0.0022 \\
{[-1.0834]}\end{array}$ & $\begin{array}{l}-0.0011 \\
{[-0.5209]}\end{array}$ & $\begin{array}{c}-0.0008 \\
{[-0.3274]}\end{array}$ & $\begin{array}{c}-0.0026 \\
{[-1.5209]}\end{array}$ & $\begin{array}{c}0.0020 \\
{[0.9164]}\end{array}$ & $\begin{array}{c}-0.0010 \\
{[-0.9639]}\end{array}$ & $\begin{array}{c}-0.0011 \\
{[-1.3311]}\end{array}$ \\
\hline Number of children & 4,074 & 6,622 & 6,671 & 4,301 & 4,635 & 3,361 & 3,257 & 2,396 & 35,317 & 35,317 \\
\hline
\end{tabular}


Table 6: Outcomes for Native Israelis - By Ethnic Origin

\begin{tabular}{|c|c|c|c|c|c|c|c|c|c|c|}
\hline & \multicolumn{10}{|c|}{ Treatment: Percentage immigrants in grade 5} \\
\hline & \multicolumn{10}{|c|}{ Number of immigrants in grades 4 to 6: } \\
\hline & $1-5$ & $6-10$ & 11-15 & $16-20$ & $21-25$ & 26-30 & 31-35 & $36-40$ & $\begin{array}{l}\text { Weighted } \\
\text { Average }\end{array}$ & $\begin{array}{c}\text { Interacted } \\
\text { Model }\end{array}$ \\
\hline \multicolumn{11}{|l|}{$\begin{array}{l}\text { A: Ethnic origin: Asia- } \\
\text { Africa }\end{array}$} \\
\hline $\begin{array}{l}\text { Quality of high school } \\
\text { attended }\end{array}$ & $\begin{array}{l}-0.0030 \\
{[-1.0638]}\end{array}$ & $\begin{array}{c}-0.0011 \\
{[-0.3772]}\end{array}$ & $\begin{array}{c}-0.0039 \\
{[-2.2850]}\end{array}$ & $\begin{array}{l}-0.0018 \\
{[-1.1918]}\end{array}$ & $\begin{array}{c}0.0012 \\
{[0.9524]}\end{array}$ & $\begin{array}{l}-0.0021 \\
{[-1.1569]}\end{array}$ & $\begin{array}{c}-0.0021 \\
{[-1.3993]}\end{array}$ & $\begin{array}{c}-0.0009 \\
{[-0.5655]}\end{array}$ & $\begin{array}{l}-0.0020 \\
{[-2.3154]}\end{array}$ & $\begin{array}{c}-0.0015 \\
{[-2.3924]}\end{array}$ \\
\hline $\begin{array}{l}\text { Dropped out before } \\
\text { completing } 12^{\text {th }} \text { grade }\end{array}$ & $\begin{array}{l}-0.0028 \\
{[-0.9217]}\end{array}$ & $\begin{array}{c}0.0009 \\
{[0.3974]}\end{array}$ & $\begin{array}{c}0.0015 \\
{[0.8113]}\end{array}$ & $\begin{array}{c}0.0035 \\
{[2.2359]}\end{array}$ & $\begin{array}{c}0.0010 \\
{[0.5733]}\end{array}$ & $\begin{array}{c}0.0025 \\
{[1.4362]}\end{array}$ & $\begin{array}{c}-0.0002 \\
{[-0.0937]}\end{array}$ & $\begin{array}{l}-0.0028 \\
{[-1.3035]}\end{array}$ & $\begin{array}{c}0.0006 \\
{[0.7643]}\end{array}$ & $\begin{array}{c}0.0009 \\
{[1.3071]}\end{array}$ \\
\hline $\begin{array}{c}\text { Passed HS } \\
\text { matriculation exam }\end{array}$ & $\begin{array}{l}-0.0113 \\
{[-2.3956]}\end{array}$ & $\begin{array}{c}-0.0021 \\
{[-0.5877]}\end{array}$ & $\begin{array}{c}-0.0059 \\
{[-1.8613]}\end{array}$ & $\begin{array}{c}-0.0012 \\
{[-0.4309]}\end{array}$ & $\begin{array}{c}-0.0043 \\
{[-1.8176]}\end{array}$ & $\begin{array}{l}-0.0038 \\
{[-1.0619]}\end{array}$ & $\begin{array}{c}-0.0039 \\
{[-1.5840]}\end{array}$ & $\begin{array}{c}0.0003 \\
{[0.1022]}\end{array}$ & $\begin{array}{c}-0.0045 \\
{[-3.5120]}\end{array}$ & $\begin{array}{c}-0.0034 \\
{[-3.0047]}\end{array}$ \\
\hline Number of children & 1,228 & 1,929 & 2,387 & 1,625 & 1,924 & 1,240 & 1,341 & 959 & 12,633 & 12,633 \\
\hline \multicolumn{11}{|l|}{ B: Ethnic origin: other } \\
\hline $\begin{array}{l}\text { Quality of high school } \\
\text { attended }\end{array}$ & $\begin{array}{c}0.0014 \\
{[0.6780]}\end{array}$ & $\begin{array}{c}-0.0002 \\
{[-0.0804]}\end{array}$ & $\begin{array}{c}-0.0014 \\
{[-0.8047]}\end{array}$ & $\begin{array}{c}0.0013 \\
{[0.9585]}\end{array}$ & $\begin{array}{c}-0.0023 \\
{[-1.4139]}\end{array}$ & $\begin{array}{c}-0.0046 \\
{[-1.7453]}\end{array}$ & $\begin{array}{c}-0.0032 \\
{[-2.2525]}\end{array}$ & $\begin{array}{c}0.0004 \\
{[0.2739]}\end{array}$ & $\begin{array}{c}-0.0010 \\
{[-1.3510]}\end{array}$ & $\begin{array}{c}-0.0011 \\
{[-1.6570]}\end{array}$ \\
\hline $\begin{array}{l}\text { Dropped out before } \\
\text { completing } 12^{\text {th }} \text { grade }\end{array}$ & $\begin{array}{l}-0.0021 \\
{[-1.0790]}\end{array}$ & $\begin{array}{c}0.0016 \\
{[1.1242]}\end{array}$ & $\begin{array}{c}0.0001 \\
{[0.0716]}\end{array}$ & $\begin{array}{c}0.0022 \\
{[2.0573]}\end{array}$ & $\begin{array}{c}-0.0004 \\
{[-0.3439]}\end{array}$ & $\begin{array}{c}0.0006 \\
{[0.5716]}\end{array}$ & $\begin{array}{c}0.0012 \\
{[0.7682]}\end{array}$ & $\begin{array}{c}-0.0011 \\
{[-0.5980]}\end{array}$ & $\begin{array}{c}0.0003 \\
{[0.5227]}\end{array}$ & $\begin{array}{c}0.0005 \\
{[0.9576]}\end{array}$ \\
\hline $\begin{array}{c}\text { Passed HS } \\
\text { matriculation exam }\end{array}$ & $\begin{array}{c}0.0039 \\
{[0.9313]}\end{array}$ & $\begin{array}{c}-0.0012 \\
{[-0.3822]}\end{array}$ & $\begin{array}{c}-0.0026 \\
{[-0.9416]}\end{array}$ & $\begin{array}{c}-0.0009 \\
{[-0.5002]}\end{array}$ & $\begin{array}{c}0.0013 \\
{[0.5658]}\end{array}$ & $\begin{array}{c}-0.0007 \\
{[-0.2633]}\end{array}$ & $\begin{array}{c}-0.0019 \\
{[-0.9768]}\end{array}$ & $\begin{array}{c}0.0019 \\
{[0.8989]}\end{array}$ & $\begin{array}{c}-0.0002 \\
{[-0.1435]}\end{array}$ & $\begin{array}{c}-0.0003 \\
{[-0.3861]}\end{array}$ \\
\hline Number of children & 3,803 & 6,054 & 5,959 & 3,736 & 3,933 & 2,846 & 2,818 & 2,211 & 31,360 & 31,360 \\
\hline
\end{tabular}


Table 7: Outcomes for Native Israelis - By Mother's Education and Ethnic Origin

\begin{tabular}{|c|c|c|c|c|c|c|c|c|c|c|}
\hline & \multicolumn{10}{|c|}{ Treatment: Percentage immigrants in grade 5} \\
\hline & \multicolumn{10}{|c|}{ Number of immigrants in grades 4 to 6: } \\
\hline & $1-5$ & $6-10$ & $11-15$ & $16-20$ & $21-25$ & $26-30$ & 31-35 & $36-40$ & $\begin{array}{c}\text { Weighted } \\
\text { Average }\end{array}$ & $\begin{array}{c}\text { Interacted } \\
\text { Model }\end{array}$ \\
\hline \multicolumn{11}{|c|}{$\begin{array}{l}\text { A: Mother's years of schooling < } 10 \text { AND } \\
\text { Ethnic Origin: Asia-Africa }\end{array}$} \\
\hline $\begin{array}{l}\text { Quality of high school } \\
\text { attended }\end{array}$ & $\begin{array}{c}-0.0111 \\
{[-1.6259]}\end{array}$ & $\begin{array}{c}0.0019 \\
{[0.5391]}\end{array}$ & $\begin{array}{c}-0.0045 \\
{[-1.4600]}\end{array}$ & $\begin{array}{c}-0.0026 \\
{[-1.2787]}\end{array}$ & $\begin{array}{c}0.0029 \\
{[1.4538]}\end{array}$ & $\begin{array}{c}0.0007 \\
{[0.1937]}\end{array}$ & $\begin{array}{c}0.0020 \\
{[0.5659]}\end{array}$ & $\begin{array}{c}0.0006 \\
{[0.1627]}\end{array}$ & $\begin{array}{l}-0.0018 \\
{[-1.2143]}\end{array}$ & $\begin{array}{c}-0.0001 \\
{[-0.1029]}\end{array}$ \\
\hline $\begin{array}{l}\text { Dropped out before } \\
\text { completing } 12^{\text {th }} \text { grade }\end{array}$ & $\begin{array}{c}0.0059 \\
{[0.8572]}\end{array}$ & $\begin{array}{c}0.0021 \\
{[0.5700]}\end{array}$ & $\begin{array}{c}0.0073 \\
{[2.4263]}\end{array}$ & $\begin{array}{c}0.0048 \\
{[1.5807]}\end{array}$ & $\begin{array}{c}0.0035 \\
{[1.2407]}\end{array}$ & $\begin{array}{c}0.0049 \\
{[1.4442]}\end{array}$ & $\begin{array}{c}-0.0036 \\
{[-1.0156]}\end{array}$ & $\begin{array}{l}-0.0107 \\
{[-4.1609]}\end{array}$ & $\begin{array}{c}0.0032 \\
{[2.0727]}\end{array}$ & $\begin{array}{c}0.0020 \\
{[1.5012]}\end{array}$ \\
\hline $\begin{array}{c}\text { Passed HS } \\
\text { matriculation exam }\end{array}$ & $\begin{array}{c}-0.0140 \\
{[-1.5604]}\end{array}$ & $\begin{array}{c}-0.0016 \\
{[-0.2591]}\end{array}$ & $\begin{array}{c}-0.0101 \\
{[-2.5427]}\end{array}$ & $\begin{array}{c}-0.0019 \\
{[-0.5075]}\end{array}$ & $\begin{array}{c}-0.0044 \\
{[-1.4686]}\end{array}$ & $\begin{array}{c}-0.0020 \\
{[-0.3016]}\end{array}$ & $\begin{array}{l}-0.0020 \\
{[-0.4750]}\end{array}$ & $\begin{array}{c}-0.0030 \\
{[-0.6893]}\end{array}$ & $\begin{array}{l}-0.0056 \\
{[-2.6438]}\end{array}$ & $\begin{array}{c}-0.0040 \\
{[-2.3935]}\end{array}$ \\
\hline Number of children & 334 & 498 & 652 & 416 & 557 & 298 & 366 & 289 & 3410 & 3410 \\
\hline \multicolumn{11}{|c|}{$\begin{array}{l}\text { B: Mother's years of schooling } \geq 10 \text { OR } \\
\text { Ethnic Origin: Other }\end{array}$} \\
\hline $\begin{array}{l}\text { Quality of high school } \\
\text { attended }\end{array}$ & $\begin{array}{c}0.0004 \\
{[0.1898]}\end{array}$ & $\begin{array}{c}-0.0007 \\
{[-0.3225]}\end{array}$ & $\begin{array}{c}-0.0024 \\
{[-1.5817]}\end{array}$ & $\begin{array}{c}0.0005 \\
{[0.3948]}\end{array}$ & $\begin{array}{c}-0.0015 \\
{[-1.0061]}\end{array}$ & $\begin{array}{c}-0.0047 \\
{[-2.0323]}\end{array}$ & $\begin{array}{c}-0.0032 \\
{[-2.3973]}\end{array}$ & $\begin{array}{c}0.0003 \\
{[0.2546]}\end{array}$ & $\begin{array}{c}-0.0015 \\
{[-2.0775]}\end{array}$ & $\begin{array}{c}-0.0014 \\
{[-2.4069]}\end{array}$ \\
\hline $\begin{array}{l}\text { Dropped out before } \\
\text { completing } 12^{\text {th }} \text { grade }\end{array}$ & $\begin{array}{c}-0.0025 \\
{[-1.3963]}\end{array}$ & $\begin{array}{c}0.0012 \\
{[0.7882]}\end{array}$ & $\begin{array}{c}-0.0003 \\
{[-0.1933]}\end{array}$ & $\begin{array}{c}0.0021 \\
{[2.1599]}\end{array}$ & $\begin{array}{c}-0.0002 \\
{[-0.2233]}\end{array}$ & $\begin{array}{c}0.0006 \\
{[0.5507]}\end{array}$ & $\begin{array}{c}0.0010 \\
{[0.7357]}\end{array}$ & $\begin{array}{c}-0.0005 \\
{[-0.3107]}\end{array}$ & $\begin{array}{c}0.0001 \\
{[0.2052]}\end{array}$ & $\begin{array}{c}0.0004 \\
{[0.8887]}\end{array}$ \\
\hline $\begin{array}{c}\text { Passed HS } \\
\text { matriculation exam }\end{array}$ & $\begin{array}{c}0.0010 \\
{[0.2586]}\end{array}$ & $\begin{array}{l}-0.0016 \\
{[-0.5953]}\end{array}$ & $\begin{array}{c}-0.0028 \\
{[-1.1549]}\end{array}$ & $\begin{array}{c}-0.0012 \\
{[-0.5934]}\end{array}$ & $\begin{array}{c}-0.0007 \\
{[-0.3568]}\end{array}$ & $\begin{array}{c}-0.0021 \\
{[-0.8832]}\end{array}$ & $\begin{array}{l}-0.0028 \\
{[-1.5471]}\end{array}$ & $\begin{array}{c}0.0026 \\
{[1.2923]}\end{array}$ & $\begin{array}{c}-0.0011 \\
{[-1.1666]}\end{array}$ & $\begin{array}{c}-0.0011 \\
{[-1.3728]}\end{array}$ \\
\hline Number of children & 4697 & 7485 & 7694 & 4945 & 5300 & 3788 & 3793 & 2881 & 40559 & 40559 \\
\hline
\end{tabular}

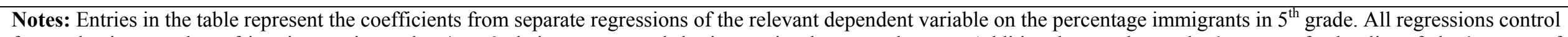

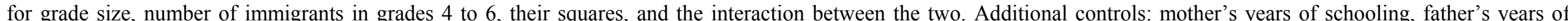

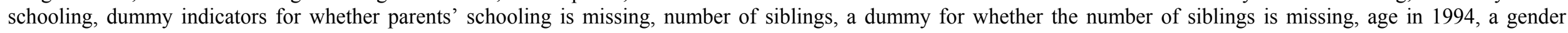

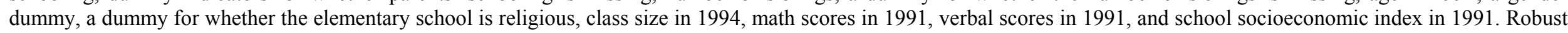
t-statistics (adjusted for clustering at the school level) in brackets. 


\section{Table 8: Outcomes for Native Israelis - By Gender}

\begin{tabular}{|c|c|c|c|c|c|c|c|c|c|c|}
\hline & \multicolumn{10}{|c|}{ Treatment: Percentage immigrants in grade 5} \\
\hline & \multicolumn{10}{|c|}{ Number of immigrants in grades 4 to 6: } \\
\hline & $1-5$ & 6-10 & 11-15 & $16-20$ & $21-25$ & 26-30 & 31-35 & $36-40$ & $\begin{array}{c}\text { Weighted } \\
\text { Average }\end{array}$ & $\begin{array}{c}\text { Interacted } \\
\text { Model }\end{array}$ \\
\hline \multicolumn{11}{|l|}{ A: Males } \\
\hline $\begin{array}{l}\text { Quality of high school } \\
\text { attended }\end{array}$ & $\begin{array}{c}-0.0037 \\
{[-1.6721]}\end{array}$ & $\begin{array}{c}-0.0004 \\
{[-0.1773]}\end{array}$ & $\begin{array}{c}-0.0033 \\
{[-1.7888]}\end{array}$ & $\begin{array}{c}-0.0001 \\
{[-0.0323]}\end{array}$ & $\begin{array}{c}-0.0018 \\
{[-1.4939]}\end{array}$ & $\begin{array}{c}-0.0033 \\
{[-1.6831]}\end{array}$ & $\begin{array}{c}-0.0025 \\
{[-1.5833]}\end{array}$ & $\begin{array}{c}0.0006 \\
{[0.3268]}\end{array}$ & $\begin{array}{c}-0.0021 \\
{[-2.8394]}\end{array}$ & $\begin{array}{c}-0.0017 \\
{[-2.6655]}\end{array}$ \\
\hline $\begin{array}{l}\text { Dropped out before } \\
\text { completing } 12^{\text {th }} \text { grade }\end{array}$ & $\begin{array}{c}-0.0042 \\
{[-1.6777]}\end{array}$ & $\begin{array}{c}0.0007 \\
{[0.2796]}\end{array}$ & $\begin{array}{c}-0.0011 \\
{[-0.5258]}\end{array}$ & $\begin{array}{c}0.0029 \\
{[1.8646]}\end{array}$ & $\begin{array}{c}-0.0005 \\
{[-0.2894]}\end{array}$ & $\begin{array}{c}0.0007 \\
{[0.5212]}\end{array}$ & $\begin{array}{c}0.0009 \\
{[0.4608]}\end{array}$ & $\begin{array}{l}-0.0033 \\
{[-1.4359]}\end{array}$ & $\begin{array}{c}-0.0005 \\
{[-0.6117]}\end{array}$ & $\begin{array}{c}-0.0001 \\
{[-0.1281]}\end{array}$ \\
\hline $\begin{array}{c}\text { Passed HS } \\
\text { matriculation exam }\end{array}$ & $\begin{array}{c}-0.0012 \\
{[-0.2485]}\end{array}$ & $\begin{array}{c}0.0003 \\
{[0.0925]}\end{array}$ & $\begin{array}{c}-0.0047 \\
{[-1.5904]}\end{array}$ & $\begin{array}{c}0.0004 \\
{[0.1729]}\end{array}$ & $\begin{array}{c}-0.0013 \\
{[-0.5154]}\end{array}$ & $\begin{array}{c}0.0019 \\
{[0.7541]}\end{array}$ & $\begin{array}{c}-0.0034 \\
{[-1.6483]}\end{array}$ & $\begin{array}{c}0.0022 \\
{[0.9270]}\end{array}$ & $\begin{array}{c}-0.0012 \\
{[-0.9884]}\end{array}$ & $\begin{array}{c}-0.0008 \\
{[-0.7941]}\end{array}$ \\
\hline Number of children & 2,626 & 3,966 & 4,339 & 2,652 & 2,977 & 2,046 & 2,163 & 1,590 & 22,359 & 22,359 \\
\hline \multicolumn{11}{|l|}{ B: Females } \\
\hline $\begin{array}{l}\text { Quality of high school } \\
\text { attended }\end{array}$ & $\begin{array}{c}0.0034 \\
{[1.3556]}\end{array}$ & $\begin{array}{c}-0.0008 \\
{[-0.3161]}\end{array}$ & $\begin{array}{c}-0.0022 \\
{[-1.3844]}\end{array}$ & $\begin{array}{c}0.0010 \\
{[0.7077]}\end{array}$ & $\begin{array}{c}0.0001 \\
{[0.0754]}\end{array}$ & $\begin{array}{c}-0.0040 \\
{[-1.4941]}\end{array}$ & $\begin{array}{c}-0.0031 \\
{[-1.8608]}\end{array}$ & $\begin{array}{c}-0.0002 \\
{[-0.1388]}\end{array}$ & $\begin{array}{c}-0.0007 \\
{[-0.8143]}\end{array}$ & $\begin{array}{c}-0.0009 \\
{[-1.3288]}\end{array}$ \\
\hline $\begin{array}{l}\text { Dropped out before } \\
\text { completing } 12^{\text {th }} \text { grade }\end{array}$ & $\begin{array}{c}0.0006 \\
{[0.3540]}\end{array}$ & $\begin{array}{c}0.0021 \\
{[1.6090]}\end{array}$ & $\begin{array}{c}0.0021 \\
{[1.1706]}\end{array}$ & $\begin{array}{c}0.0024 \\
{[1.9453]}\end{array}$ & $\begin{array}{c}0.0014 \\
{[1.2467]}\end{array}$ & $\begin{array}{c}0.0006 \\
{[0.5934]}\end{array}$ & $\begin{array}{c}0.0006 \\
{[0.4193]}\end{array}$ & $\begin{array}{c}0.0000 \\
{[0.0138]}\end{array}$ & $\begin{array}{c}0.0015 \\
{[2.5538]}\end{array}$ & $\begin{array}{c}0.0014 \\
{[2.6416]}\end{array}$ \\
\hline $\begin{array}{c}\text { Passed HS } \\
\text { matriculation exam }\end{array}$ & $\begin{array}{c}0.0008 \\
{[0.1620]}\end{array}$ & $\begin{array}{c}-0.0038 \\
{[-1.1421]}\end{array}$ & $\begin{array}{c}-0.0031 \\
{[-1.0074]}\end{array}$ & $\begin{array}{c}-0.0020 \\
{[-0.8821]}\end{array}$ & $\begin{array}{c}-0.0013 \\
{[-0.6761]}\end{array}$ & $\begin{array}{c}-0.0062 \\
{[-2.2807]}\end{array}$ & $\begin{array}{c}-0.0018 \\
{[-0.8210]}\end{array}$ & $\begin{array}{c}0.0015 \\
{[0.4653]}\end{array}$ & $\begin{array}{c}-0.0021 \\
{[-1.7013]}\end{array}$ & $\begin{array}{c}-0.0021 \\
{[-2.1477]}\end{array}$ \\
\hline Number of children & 2,402 & 4,012 & 4,001 & 2,705 & 2,876 & 2,040 & 1,995 & 1,579 & 21,610 & 21,610 \\
\hline
\end{tabular}


Table 9: Comparison of Methods

\begin{tabular}{|c|c|c|c|c|c|c|c|}
\hline & $\begin{array}{c}\text { (1) } \\
\text { OLS }\end{array}$ & $\begin{array}{c}(2) \\
\text { OLS }\end{array}$ & $\begin{array}{c}\text { (3) } \\
\text { OLS }\end{array}$ & $\begin{array}{c}\text { (4) } \\
\text { OLS }\end{array}$ & $\begin{array}{c}\text { (5) } \\
\text { OLS }\end{array}$ & $\begin{array}{c}\text { (6) } \\
\begin{array}{c}\text { Fully interacted } \\
\text { model }\end{array}\end{array}$ & $\begin{array}{c}\text { (7) } \\
\text { Weighted } \\
\text { Average Model } \\
\end{array}$ \\
\hline \multicolumn{8}{|l|}{ A: Full Sample } \\
\hline Quality of high school & -0.0041 & -0.0030 & -0.0005 & -0.0003 & -0.0012 & -0.0012 & -0.0013 \\
\hline attended & {$[-7.5179]$} & {$[-6.0698]$} & {$[-1.1508]$} & {$[-0.5240]$} & {$[-2.0865]$} & {$[-2.1779]$} & {$[-1.8585]$} \\
\hline Dropped out before & 0.0025 & 0.0015 & 0.0006 & 0.0008 & 0.0005 & 0.0007 & 0.0005 \\
\hline completing $12^{\text {th }}$ grade & {$[6.9866]$} & [4.6704] & [1.9942] & {$[1.6883]$} & {$[0.9160]$} & {$[1.3827]$} & {$[0.8492]$} \\
\hline Passed HS matriculation & -0.0061 & -0.0033 & -0.0013 & -0.0015 & -0.0015 & -0.0014 & -0.0015 \\
\hline exam & {$[-9.2099]$} & {$[-6.1093]$} & {$[-2.5999]$} & {$[-2.0916]$} & {$[-1.9777]$} & {$[-1.8450]$} & {$[-1.6033]$} \\
\hline \multicolumn{8}{|l|}{$\begin{array}{c}\text { B: Mother's years of } \\
\text { schooling }<10\end{array}$} \\
\hline $\begin{array}{l}\text { Quality of high school } \\
\text { attended }\end{array}$ & $\begin{array}{c}-0.0039 \\
{[-5.3894]}\end{array}$ & $\begin{array}{c}-0.0031 \\
{[-4.8960]}\end{array}$ & $\begin{array}{c}-0.0002 \\
{[-0.3610]}\end{array}$ & $\begin{array}{c}0.0001 \\
{[0.1274]}\end{array}$ & $\begin{array}{c}-0.0005 \\
{[-0.5007]}\end{array}$ & $\begin{array}{c}-0.0006 \\
{[-0.7194]}\end{array}$ & $\begin{array}{c}-0.0012 \\
{[-1.2763]}\end{array}$ \\
\hline Dropped out before & 0.0030 & 0.0019 & 0.0007 & 0.0016 & 0.0009 & 0.0011 & 0.0020 \\
\hline completing $12^{\text {th }}$ grade & {$[3.6436]$} & {$[2.5723]$} & {$[0.9812]$} & {$[1.5872]$} & {$[0.7936]$} & {$[1.1925]$} & {$[1.6995]$} \\
\hline Passed HS matriculation & -0.0046 & -0.0034 & -0.0013 & -0.0029 & -0.0028 & -0.0025 & -0.0045 \\
\hline exam & {$[-4.7928]$} & {$[-3.8583]$} & {$[-1.4304]$} & {$[-2.4341]$} & {$[-2.0409]$} & {$[-1.7764]$} & {$[-2.6166]$} \\
\hline \multicolumn{8}{|l|}{$\begin{array}{l}\text { C: Ethnic Group: Asia- } \\
\text { Africa }\end{array}$} \\
\hline Quality of high school & -0.0033 & -0.0025 & -0.0007 & -0.0008 & -0.0016 & -0.0015 & -0.0020 \\
\hline attended & {$[-5.9450]$} & {$[-4.8518]$} & {$[-1.4656]$} & {$[-1.3133]$} & {$[-2.3576]$} & {$[-2.3924]$} & {$[-2.3154]$} \\
\hline Dropped out before & 0.0027 & 0.0017 & 0.0012 & 0.0012 & 0.0008 & 0.0009 & 0.0006 \\
\hline completing $12^{\text {th }}$ grade & {$[5.3665]$} & [3.6639] & {$[2.4051]$} & {$[1.7794]$} & {$[1.0415]$} & {$[1.3071]$} & {$[0.7643]$} \\
\hline Passed HS matriculation & -0.0052 & -0.0032 & -0.0023 & -0.0032 & -0.0035 & -0.0034 & -0.0045 \\
\hline exam & {$[-6.8231]$} & {$[-4.4805]$} & {$[-3.1966]$} & {$[-3.3338]$} & {$[-3.3669]$} & {$[-3.0047]$} & {$[-3.5120]$} \\
\hline Individual controls & No & Yes & Yes & Yes & Yes & Yes & Yes \\
\hline School controls & No & No & Yes & Yes & Yes & Yes & Yes \\
\hline Control function & None & None & None & Linear & $\begin{array}{l}\text { Flexible } \\
\text { polynomial }\end{array}$ & $\begin{array}{c}\text { Flexible } \\
\text { polynomial }\end{array}$ & $\begin{array}{c}\text { Flexible } \\
\text { polynomial }\end{array}$ \\
\hline $\begin{array}{l}\text { Interval dummies and } \\
\text { interactions }\end{array}$ & No & No & No & No & No & Yes & -- \\
\hline
\end{tabular}


Table 10: The Impact of May 1991 Ethiopian Immigrants -- Balancing Tests

\begin{tabular}{|c|c|c|c|c|}
\hline & \multicolumn{4}{|c|}{ Number of Ethiopian immigrants in grades 4 to 6: } \\
\hline & $1-5$ & 6-10 & 11-15 & 16-20 \\
\hline Mother's years of schooling & $\begin{array}{c}-0.0741 \\
{[-1.0498]}\end{array}$ & $\begin{array}{c}-0.0194 \\
{[-0.4335]}\end{array}$ & $\begin{array}{c}-0.0438 \\
{[-0.4837]}\end{array}$ & $\begin{array}{c}-0.0462 \\
{[-3.3963]}\end{array}$ \\
\hline Father's years of schooling & $\begin{array}{c}-0.0759 \\
{[-0.9641]}\end{array}$ & $\begin{array}{c}-0.0204 \\
{[-0.4876]}\end{array}$ & $\begin{array}{c}-0.0841 \\
{[-1.0610]}\end{array}$ & $\begin{array}{c}-0.0469 \\
{[-2.7201]}\end{array}$ \\
\hline $\begin{array}{l}\text { Number of } \\
\text { Siblings }\end{array}$ & $\begin{array}{c}-0.0330 \\
{[-0.7081]}\end{array}$ & $\begin{array}{c}-0.0538 \\
{[-1.5223]}\end{array}$ & $\begin{array}{c}-0.0399 \\
{[-0.9015]}\end{array}$ & $\begin{array}{c}-0.0088 \\
{[-0.5053]}\end{array}$ \\
\hline $\begin{array}{l}\text { Fraction } \\
\text { Asia-Africa }\end{array}$ & $\begin{array}{c}-0.0081 \\
{[-0.9349]}\end{array}$ & $\begin{array}{c}-0.0010 \\
{[-0.2577]}\end{array}$ & $\begin{array}{c}0.0091 \\
{[1.0298]}\end{array}$ & $\begin{array}{c}0.0064 \\
{[1.7347]}\end{array}$ \\
\hline Standardized math score in 1991 & $\begin{array}{c}-0.0066 \\
{[-0.1514]}\end{array}$ & $\begin{array}{c}0.0372 \\
{[1.5055]}\end{array}$ & $\begin{array}{c}0.0046 \\
{[0.1477]}\end{array}$ & $\begin{array}{c}0.0126 \\
{[0.8993]}\end{array}$ \\
\hline Standardized verbal score in 1991 & $\begin{array}{c}-0.0244 \\
{[-0.5807]}\end{array}$ & $\begin{array}{c}0.0051 \\
{[0.2021]}\end{array}$ & $\begin{array}{c}0.0131 \\
{[0.6484]}\end{array}$ & $\begin{array}{c}-0.0039 \\
{[-0.4435]}\end{array}$ \\
\hline Socioeconomic index in 1991 & $\begin{array}{c}0.0155 \\
{[0.2959]}\end{array}$ & $\begin{array}{c}0.0049 \\
{[0.1663]}\end{array}$ & $\begin{array}{c}-0.0360 \\
{[-0.9839]}\end{array}$ & $\begin{array}{c}-0.0325 \\
{[-2.6015]}\end{array}$ \\
\hline $\begin{array}{l}\text { Class size in } \\
1994\end{array}$ & $\begin{array}{c}0.3424 \\
{[1.3459]}\end{array}$ & $\begin{array}{c}0.1359 \\
{[0.7982]}\end{array}$ & $\begin{array}{c}0.4289 \\
{[2.0185]}\end{array}$ & $\begin{array}{c}0.3289 \\
{[3.6307]}\end{array}$ \\
\hline Number of schools & 95 & 48 & 20 & 16 \\
\hline Number of children & 4,411 & 3,600 & 858 & 606 \\
\hline $\begin{array}{l}\text { Average number of children in } 5^{\text {th }} \\
\text { grade }\end{array}$ & 57.17 & 45.54 & 52.40 & 52.43 \\
\hline $\begin{array}{l}\text { Average number of Ethiopian } \\
\text { immigrants in } 5^{\text {th }} \text { grade }\end{array}$ & 0.89 & 2.58 & 4.50 & 6.13 \\
\hline $\begin{array}{l}\text { Average Percentage Ethiopian } \\
\text { Immigrants in } 5^{\text {th }} \text { grade }\end{array}$ & 2.30 & 6.83 & 9.48 & 13.41 \\
\hline $\begin{array}{l}\text { Standard deviation of } \% \text { Ethiopian } \\
\text { Immigrants in } 5^{\text {th }} \text { grade }\end{array}$ & 3.33 & 28.57 & 5.88 & 12.69 \\
\hline
\end{tabular}

Notes: Entries in the table represent the coefficients from separate regressions of the relevant dependent variable on the percentage immigrants in $5^{\text {th }}$ grade. All regressions control for number of May 1991 Ethiopians in grades 4 to 6, the number of children in grade 5, their squares, and the interaction between the two. Robust t-statistics, adjusted for clustering at the school level, in brackets. 
Table 11: The Impact of May 1991 Ethiopian Immigrants - Outcomes

\begin{tabular}{|c|c|c|c|c|c|c|}
\hline & \multicolumn{6}{|c|}{ Treatment: Percentage Ethiopian immigrants in grade 5} \\
\hline & \multicolumn{6}{|c|}{ Number of Ethiopian immigrants in grades 4 to 6: } \\
\hline & $1-5$ & 6-10 & 11-15 & $16-20$ & Weighted Average & $\begin{array}{l}\text { Interacted } \\
\text { Model }\end{array}$ \\
\hline \multicolumn{7}{|l|}{ A: All native children } \\
\hline Quality of high school attended & $\begin{array}{c}-0.0020 \\
{[-0.5104]}\end{array}$ & $\begin{array}{c}0.0030 \\
{[1.2597]}\end{array}$ & $\begin{array}{c}-0.0081 \\
{[-3.1083]}\end{array}$ & $\begin{array}{c}-0.0047 \\
{[-2.9496]}\end{array}$ & $\begin{array}{c}-0.0016 \\
{[-0.7186]}\end{array}$ & $\begin{array}{c}-0.0021 \\
{[-1.5436]}\end{array}$ \\
\hline $\begin{array}{l}\text { Dropped out before completing } \\
\qquad 12^{\text {th }} \text { grade }\end{array}$ & $\begin{array}{c}-0.0039 \\
{[-0.8552]}\end{array}$ & $\begin{array}{c}0.0011 \\
{[0.5625]}\end{array}$ & $\begin{array}{c}0.0026 \\
{[1.0307]}\end{array}$ & $\begin{array}{l}0.0020 \\
{[1.6791]}\end{array}$ & $\begin{array}{c}-0.0013 \\
{[-0.5184]}\end{array}$ & $\begin{array}{c}0.0009 \\
{[0.7127]}\end{array}$ \\
\hline Passed HS matriculation exam & $\begin{array}{c}0.0045 \\
{[0.7862]}\end{array}$ & $\begin{array}{c}-0.0071 \\
{[-2.8673]}\end{array}$ & $\begin{array}{c}-0.0189 \\
{[-3.5520]}\end{array}$ & $\begin{array}{c}-0.0033 \\
{[-2.4028]}\end{array}$ & $\begin{array}{c}-0.0019 \\
{[-0.6020]}\end{array}$ & $\begin{array}{c}-0.0056 \\
{[-3.2138]}\end{array}$ \\
\hline$N$ & 4,411 & 1,683 & 858 & 606 & 7,558 & 7,552 \\
\hline \multicolumn{7}{|l|}{$\begin{array}{l}\text { B: Mother's years of schooling } \\
<10\end{array}$} \\
\hline Quality of high school attended & $\begin{array}{l}-0.0033 \\
{[-0.5433]}\end{array}$ & $\begin{array}{c}0.0005 \\
{[0.1328]}\end{array}$ & $\begin{array}{c}-0.0199 \\
{[-2.8450]}\end{array}$ & $\begin{array}{c}0.0018 \\
{[0.9497]}\end{array}$ & $\begin{array}{c}-0.0037 \\
{[-1.0634]}\end{array}$ & $\begin{array}{c}-0.0018 \\
{[-0.8369]}\end{array}$ \\
\hline $\begin{array}{l}\text { Dropped out before completing } \\
\qquad 12^{\text {th }} \text { grade }\end{array}$ & $\begin{array}{c}-0.0147 \\
{[-1.7961]}\end{array}$ & $\begin{array}{c}0.0031 \\
{[0.6682]}\end{array}$ & $\begin{array}{c}0.0030 \\
{[0.6004]}\end{array}$ & $\begin{array}{c}0.0033 \\
{[1.8792]}\end{array}$ & $\begin{array}{c}-0.0063 \\
{[-1.3874]}\end{array}$ & $\begin{array}{c}0.0006 \\
{[0.2438]}\end{array}$ \\
\hline Passed HS matriculation exam & $\begin{array}{c}0.0212 \\
{[2.7300]}\end{array}$ & $\begin{array}{l}-0.0162 \\
{[-3.1356]}\end{array}$ & $\begin{array}{l}-0.0396 \\
{[-8.5441]}\end{array}$ & $\begin{array}{c}-0.0013 \\
{[-0.4330]}\end{array}$ & $\begin{array}{c}0.0023 \\
{[0.5350]}\end{array}$ & $\begin{array}{l}-0.0072 \\
{[-2.1084]}\end{array}$ \\
\hline$N$ & 1,414 & 700 & 313 & 232 & 2,659 & 2,659 \\
\hline \multicolumn{7}{|l|}{ C: Ethnic Origin: Asia-Africa } \\
\hline Quality of high school attended & $\begin{array}{c}-0.0005 \\
{[-0.1375]}\end{array}$ & $\begin{array}{c}0.0023 \\
{[0.8136]}\end{array}$ & $\begin{array}{c}-0.0104 \\
{[-2.5757]}\end{array}$ & $\begin{array}{c}-0.0038 \\
{[-1.8149]}\end{array}$ & $\begin{array}{c}-0.0011 \\
{[-0.5565]}\end{array}$ & $\begin{array}{c}-0.0016 \\
{[-1.0644]}\end{array}$ \\
\hline $\begin{array}{l}\text { Dropped out before completing } \\
12^{\text {th }} \text { grade }\end{array}$ & $\begin{array}{c}-0.0053 \\
{[-1.1079]}\end{array}$ & $\begin{array}{c}0.0005 \\
{[0.1762]}\end{array}$ & $\begin{array}{c}0.0034 \\
{[1.1944]}\end{array}$ & $\begin{array}{c}0.0068 \\
{[4.5562]}\end{array}$ & $\begin{array}{c}-0.0017 \\
{[-0.6286]}\end{array}$ & $\begin{array}{c}0.0024 \\
{[1.4196]}\end{array}$ \\
\hline Passed HS matriculation exam & $\begin{array}{c}0.0019 \\
{[0.2463]}\end{array}$ & $\begin{array}{l}-0.0100 \\
{[-2.9127]}\end{array}$ & $\begin{array}{c}-0.0199 \\
{[-2.6894]}\end{array}$ & $\begin{array}{c}-0.0016 \\
{[-0.8336]}\end{array}$ & $\begin{array}{l}-0.0040 \\
{[-0.9244]}\end{array}$ & $\begin{array}{c}-0.0063 \\
{[-2.8536]}\end{array}$ \\
\hline$N$ & 1,553 & 735 & 320 & 249 & 2,857 & 2,857 \\
\hline
\end{tabular}

